\title{
Mateusz Mataniak*
}

\section{Monopol solny w Wolnym Mieście Krakowie (1815-1846). Organizacja i zakres kompetencji Straży Solnej Wolnego Miasta Krakowa}

W niniejszym artykule przedstawiono zasady organizacyjne oraz formy działalności Straży Solnej w Wolnym Mieście Krakowie (dalej: WMK), w latach 1815-1847. W przeciwieństwie do Administracji Salinarnej w Wieliczce, która doczekała się kilku wartościowych opracowań, stan badań nad administracją solną w Rzeczypospolitej Krakowskiej jest całkowicie niezadowalający ${ }^{1}$. Stąd też, podstawę dla prezentowanych rozważań stanowiły w głównej mierze materiały archiwalne, przechowywane w Archiwum Narodowym w Krakowie. W pierwszym rzędzie wskazać należy tzw. akta senackie, składające się na spuściznę aktową po działalności Senatu Rządzącego, sprawującego w WMK naczelną władzę rządową. W dalszej kolejności wymienić trzeba akta budżetowe WMK oraz dzienniki rządowe². W pracy nie wykorzystano obfitych zbiorów tzw. Archiwum Salinarnego

${ }^{*}$ historyk prawa, doktor nauk prawnych Uniwersytetu Jagiellońskiego, współpracownik Katedr Historyczno-Prawnych UJ; absolwent historii (Uniwersytet Pedagogiczny im. KEN w Krakowie); zainteresowania badawcze: administracja skarbowa Wolnego Miasta Krakowa, Urząd Wojewódzki w Krakowie (1921-1939, 1945-1950); e-mail: aramis221@wp.pl

${ }^{1} \mathrm{O}$ administracji salinarnej w Wieliczce pisał Łukasz Walczy, Przemiany organizacyjne oraz kadra urzędnicza $w$ Żupach Krakowskich $w$ poczatkowym okresie administracji austriackiej (1772-1809), „Studia i Materiały do Dziejów Żup Solnych w Polsce” 1996, t. 19, s. 111-156; id em, Zarzadzanie salinami krakowskimi w okresie zaboru austriackiego (1772-1918), „Studia i Materiały do Dziejów Żup Solnych w Polsce” 2002, t. 22, s. 57-78. Zob. też Kazimierz Dziwik, Saliny Krakowskie w latach 1772-1918, [w:] Dzieje Żup Krakowskich, Wieliczka 1988, s. 223-303.

${ }^{2}$ Spośród akt senackich najważniejsze były materiały fascykułu 47 (,,Sól - monopolium 1816-1853”), sygn. WMK V-115 oraz fascykułu 58 („Celne 1841-1854”), sygn. WMK V-151. Utrudnienie stanowił fakt wybrakowania (,wyszkartowania”) akt Wydziału Dochodów Publicznych i Skarbu jeszcze w XIX w. 
w Wieliczce, ponieważ w dostępnych inwentarzach nie odnaleziono śladów dokumentacji związanej z kontaktami między rządem w Krakowie a wielicką Administracją Salinarną ${ }^{3}$.

Sól należy do środków spożywczych niezbędnych ludzkiemu organizmowi. Nic więc dziwnego, że również władze WMK starały się na bieżąco zaspokajać potrzeby mieszkańców Krakowa (ponad 23000 osób w 1815 r. blisko $43000 \mathrm{w} 1843$ r.), trzech miasteczek (Chrzanów, Trzebinia, Nowa Góra) oraz 224 wsi okręgowych, w tym zakresie ${ }^{4}$. W bezpośrednim sąsiedztwie Krakowa duże składy solne znajdowały się na Podgórzu (skład Kazimierski-Podgórski) ${ }^{5}$ oraz w Niepołomicach i Sierosławicach, odleglejsze zaś w Wieliczce i Bochni ${ }^{6}$.

Należy zwrócić uwagę, że podobnie jak władze Księstwa Warszawskiego bądź Królestwa Polskiego, rząd WMK posiadał monopol solny. Polegał on

${ }^{3} \mathrm{O}$ zasobach Archiwum Muzeum Żup Krakowskich zob. Kazimierz Dziwik, Katalog rękopisów Muzeum Żup Krakowskich z lat 1518-1971, Wieliczka 1988; idem, Katalog dokumentów Muzeum Żup Krakowskich z lat 1492-1777, Wieliczka 1979; Marcin Marynow ski, Leszek Rzepka, Inwentarz Akt Salinarnych Wieliczki i Bochni z lat 1772-1918, Wieliczka 2004; Le szek Rzepka, Informator o zasobie historycznym Archiwum Muzeum Żup Krakowskich Wieliczka, „Studia i Materiały do Dziejów Żup Solnych w Polsce” 1996, t. 19, s. 239-249; idem, Austriackie akta normatywne 1750-1868 w zasobie Archiwum Muzeum Żup Krakowskich Wieliczka, ,Studia i Materiały do Dziejów Żup Solnych w Polsce" 2011, t. 27, s. 317-320.

${ }^{4}$ Janina Bieniarzówna, Jan M. Małecki, Dzieje Krakowa, t. 3: Kraków w latach 1796-1918, Kraków 1979, s. 44-45; Wojciech M. Bartel, Ustrój i prawo Wolnego Miasta Krakowa (1815-1846), Biblioteka Krakowska nr 116, Kraków 1976, s. 8-9. W 1843 r. w okręgu zamieszkiwało 102797 osób, w Krakowie blisko 43000.

${ }^{5}$ Skład solny podgórski znajdował się naprzeciwko Cegielni Rządowej na Kazimierzu, Małgorzata Międzobrodzka, Kazimierski-Podgórski skład solny (XVI-XIX w.), „Studia i Materiały do Dziejów Żup Solnych w Polsce” 2016, t. 31, s. 39. Zob. ANK, Zbiór kartograficzny, sygn. II-29 („Plan Wolnego Miasta Krakowa w obrębie okopów” z 1831 r.); ANK, Zbiór kartograficzny, sygn. I-36 (plan „Umgebungen von Krakau in achten Blättern” z 1846 r.) oraz Plan Krakowa w obrębie okopów z 1836 r. opublikowany [w:] Atlas Historyczny Miast Polskich, red. Roman Czaja, t. 5: Małopolska, red. Zdzisław Noga, z. 1: Kraków, red. Z. Noga, Kraków 2007 (plan 1.21).

${ }^{6}$ K. Dziwik, Saliny Krakowskie..., s. 293-295. Szerzej zob. M. Międzobrodzka, Kazimierski-Podgórski skład solny..., s. 9-57; eadem, Handel sola w wielkim Krakowie, „Studia i Materiały do Dziejów Żup Solnych w Polsce” 2007, t. 25, s. 11-25. O solnictwie galicyjskim zob. Danuta Dobrowolska, Antonina Keckowa, Solnictwo, [w:] Zarys dziejów górnictwa na ziemiach polskich, t. 2, red. Jan Pazdur, Katowice 1961, s. $140-154$. 
na wyłącznym korzystaniu z prawa do czerpania dochodów ze sprzedaży soli, co wiązało się także z ustalaniem jej ceny rynkowej, udzielaniem koncesji na sprzedaż detaliczną oraz zwalczaniem nielegalnego jej sprowadzania i sprzedaży. W związku z jego wprowadzaniem władze rozbudowywały infrastrukturę magazynową, organizując też administrację zajmującą się handlem i wewnętrzną hurtową dystrybucją soli. Wyłączność państwa była przy tym wynikiem wprowadzonego ustawodawstwa, a nie siły ekonomicznej ${ }^{7}$.

Władze WMK nabywały sól przede wszystkim w żupach wielickich. Od 1787 r. nadzór nad sprzedażą tamtejszej soli (w tym: organizacja dostaw do głównych składów solnych, ustalanie cen, zawieranie kontraktów) spoczywał na Galicyjskiej Dyrekcji dla Spraw Solnych we Lwowie („Galizische Salzwesens-Direktion”), od 1817 r. do Galicyjskiej Dyrekcji Sprzedaży Soli w Wieliczce ${ }^{8}$.

W 1816 r. Senat Rządzący zwrócił się, za pośrednictwem komisarza (rezydenta) Józefa Sweerts-Sporka, do rządu w Wiedniu o zawarcie kontraktu na zakup w Wieliczce 60000 cetnarów soli rocznie ${ }^{9}$. Wkrótce oczywiste stało się, że rynek wewnętrzny WMK nie jest w stanie wchłonąć tak dużej ilości soli (jego zdolność w tej mierze szacowano na ok. 18000 cetnarów). Senat zdecydował się jednak na oddanie ,przedsiębiorstwa dostaw soli” w ręce powstałej w 1812 r. Kompanii Handlowej Soli Warzonej w Warszawie. Jej wspólnikami byli Berek Szmul Sonnenberg, jego szwagier, warszawski bankier Samuel Fraenkel, a także Ignacy Neumark, Józef Grunbaum, Salomon (Samuel) Posner oraz Salomon Bornstein z Wieliczki. Kontrakt podpisano 6 marca 1816 r. Zgodnie z nim, członkowie Kompanii mieli wnosić do Skarbu Publicznego WMK opłatę dzierżawną w wysokości 110000 złp, uiszczaną comiesięcznie, w ratach po 10176 złp. W zamian uzyskiwali wyłączne prawo sprowadzania i sprzedaży hurtowej soli szybikowatej oraz

${ }^{7}$ Lesław Pauli, Monopol, [w:] Encyklopedia historii gospodarczej Polski do 1945 roku, t. 1, red. Antoni Mączak, Warszawa 1981, s. 566-567. Zob. też Rafał Kowalczyk, Polityka gospodarcza i finansowa Księstwa Warszawskiego w latach 1807-1812, Łódź 2010, s. 129, 225-226; i dem, ,Polityka solna” w Księstwie Warszawskim w latach 1807-1815, „Przegląd Historyczny” 2009, t. 100, z. 4, s. 761.

${ }^{8}$ Ł. Walczy, Zarzqdzanie salinami krakowskimi..., s. 61-62; K. Dziwik, Saliny krakowskie..., s. 229-230. Produkcję soli organizowała zaś Administracja Górnicza i Salinarna.

${ }^{9}$ ANK, Archiwum Wolnego Miasta Krakowa, sygn. WMK V-115, s. 231-232 (pismo Senatu Rządzącego do komisarza pełnomocnego rządu austriackiego z 26 stycznia 1816, nr 240). 
zielonej, przy zastosowaniu tzw. miar berlińskich $(1$ cetnar berliński $=126$ funtów wagi polskiej, czyli ponad $50 \mathrm{~kg})^{10}$. Dostawy miały objąć 60000 cetnarów soli. Cenę 1 cetnara ustalono odgórnie początkowo na $20 \mathrm{złp}$ (do 1 czerwca 1816 - na 23 złp). Sól miała być czysta, nie zawierać „błota, piasku i innych nieczystości”. Kompanię zobowiązano do wpłacenia kaucji (10 000 złp) w gotówce bądź z zabezpieczeniem hipotecznym. Co istotne, miała ona również utrzymywać „Straż Solną od defraudacji”, współpracującą z Milicją Krajową, strażą rogatkową, wójtami gminnymi oraz innym służbami odpowiedzialnymi za bezpieczeństwo w WMK. We wszystkich czynnościach strażników solnych mieli brać udział urzędnicy Wolnego Miasta. Wprowadzanie soli do miasta mogło następować jedynie w wyznaczonych punktach (przez most na rogatce miejskiej nr I). Osobom pochwyconym na próbie przemytu (defraudacji) miano odbierać prawo prowadzenia działalności gospodarczej (konsens), z wyłączeniem prawa jego otrzymania w przyszłości. Skonfiskowaną sól miano przechowywać w składzie entrepryzy (podręczny magazyn Kompanii), a następnie rozdzielać między dzierżawcę oraz strażnika (bądź donoszącego o przemycie, czyli denuncjatora). Karę pieniężną ustalono na 200 złp od każdego przemyconego cetnara soli. Kupowanie soli na własne potrzeby, powyżej określonego limitu (1 cetnar), wymagało okazania świadectwa wystawionego przez wójta, co nie dotyczyło jedynie mieszkańców Krakowa. Monopol wypuszczono w dzierżawę bez prawa ewikcji, co skutkowało tym, że nabywcy soli nie mogli występować z pretensjami do Skarbu Publicznego z powodu nieprawidłowości w poczynaniach Kompanii. Z natury umowy wynikało, że władze WMK nie gwarantowały sprzedaży całości zakontraktowanej soli, przedsiębiorcy nie mogli więc występować z jakimikolwiek pretensjami; Senat zobowiązał się jedynie do bieżącego monitorowania sytuacji na rynku w kwestii zapotrzebowania na sól „na konsumpcję wewnętrzną”. W gromadzeniu danych statystycznych miała uczestniczyć również Kompania Solna. „Moc egzekucyjną" nadawało kontraktowi dopiero jego zatwierdzenie przez Senat. Umowa miała obowiązywać od 1 marca 1816 do 31 maja $1821^{11}$. Jeszcze

${ }^{10}$ Ireneusz Ihnatowicz, Vademecum do badań nad historia XIX i XX wieku, t. 1, Warszawa 1967, s. 51-53. 1 funt polski (warszawski) $=0,40 \mathrm{~kg}$; 1 cetnar galicyjski $=40,5 \mathrm{~kg}$; 1 cetnar pruski $=51,45 \mathrm{~kg}$.

${ }^{11}$ ANK, Archiwum Wolnego Miasta Krakowa, sygn. WMK V-115, s. 309-316 (projekt kontraktu z 4 marca 1816). Pełnomocnikami rządu byli Antoni Morbitzer i Józef Micha- 
w 1816 r. Kompania zatrudniła odpowiednią liczbę strażników solnych, pieszych i konnych ${ }^{12}$.

W 1817 r. w umowie wprowadzono pewne modyfikacje. Potwierdzono wielkość dostawy na 60000 cetnarów soli, w terminie czteroletnim (do 1 czerwca 1821 r.). Opłatę dzierżawną (tenuta) rząd WMK ustalił na $120000 \mathrm{złp} \mathrm{rocznie,} \mathrm{płatne} \mathrm{w}$ miesięcznych ratach ${ }^{13}$.

Umowę przedłużono w 1820 r. (z mocą obowiązującą od roku następnego). Tenutę podwyższono do 180000 złp rocznie. Senat wprowadził karę 3000 złp za każdy dzień opóźnienia w dostawach. Sprowadzana miała być jedynie sól wysokiej jakości. 100 cetnarów soli rocznie Kompania miała nieodpłatnie odstępować na rzecz instytucji dobroczynnych (np. Towarzystwo Dobroczynności, Arcybractwo Miłosierdzia i Banku Pobożnego w Krakowie) ${ }^{14}$. Ponieważ oczekiwano, że rząd Królestwa Polskiego przystapi do negocjacji w sprawie obniżenia ceny zakupu soli wielickiej, co pozwoliłoby, przy zachowaniu zysków, obniżyć cenę zbytu soli w Krakowie z 21 do 15 złp (z korzyścią dla mieszkańców WMK), w umowie wprowadzono klauzulę, że w razie jej nieobniżenia przez rząd austriacki, z 11 do 7 złp, kontrakt miał obowiązywać do 31 maja 1822 r. W przeciwnym razie wygasłby do-

łowski. Warto dodać, że w tym samym okresie Kompania dzierżawiła monopol solny w Królestwie Polskim, co przynosiło jej wręcz kolosalne zyski.

${ }^{12}$ Ibidem, s. 281 („Lista ustanowionych przez Entrepryzę Soli Strażników” z 26 marca 1816); s. 271 („Lista imienna Nadstrażnika i Strażników Solnych w Wolnym Mieście i Okręgu Krakowa" z 15 kwietnia 1816). W Krakowie byli to: Jakub Lodziński (nadstrażnik), Franciszek Schortz (Szorc), Jan Włodarski, Jakub Lewandowski, Mikołaj Wyrwań, Adam Flaszkiewicz, Józef Smoleński, Florian Czyżewski, w okolicach Chrzanowa czterej strażnicy konni (Jan Żabiński, Józef Judkiewicz, Jakub Płonkowski, Gronek Graner).

${ }^{13}$ Ibidem, s. 231-232, 461 (pismo Wydziału Dochodów Publicznych do Senatu Rządzącego z 18 czerwca 1817; pisma komisarza pełnomocnego rządu austriackiego do Senatu Rządzącego z 21 kwietnia 1816 i 1 lipca 1816); s. 462-463 (pismo Senatu Rządzącego do Wydziału Dochodów Publicznych i komisarza pełnomocnego z 18 czerwca 1817, nr 1747 - zgoda na zawarcie kontraktu). Rząd austriacki domagał się wprowadzenia zakazu wwożenia soli do WMK przez ,wolnych handlarzy galicyjskich”.

${ }^{14}$ Ibidem, s. 155-156 (pismo senatorów delegowanych do Senatu Rządzącego z 22 stycznia 1820; pismo Senatu Rządzącego do senatora Wojciecha Kucieńskiego i pełnomocników Kompanii Solnej z 22 stycznia 1820, nr 226); s. 157-164 (,Zasady kontraktu do wydzierżawienia prawa wyłącznego sprzedaży soli w Mieście Krakowie i Jego Okręgu od dnia 1 czerwca 1821 roku” z 18 stycznia 1820. Pod umową podpisali się senatorowie W. Kucieński, Mikołaj Hoszowski, Antoni Bystrzonowski, Feliks Grodzicki, a także pełnomocnicy Kompanii Solnej: Salomon Samson Neumark, Gabriel Bereksohn). 
piero 31 maja 1827 r. Pod naciskiem władz Królestwa Senat zgodził się, aby sól sprzedawano po 15 złp za 1 cetnar miary berlińskiej (marża entreprenera wynosiła $7 \mathrm{zlp})^{15}$.

Warunki umowy z 1820 r. doprecyzowano w akcie notarialnym ${ }^{16}$. Znalazły się w nim m.in. bliższe informacje dotyczące funkcjonowania Straży Solnej („straż monopoliczna”). Miała ona otrzymywać wszelką niezbędną pomoc ze strony „policji, milicji oraz strażników rogatkowych”, a w granicach okręgu - również od wójtów (początkowo wskazano też burmistrzów). Współpraca miała obejmować zwłaszcza ,ściganie defraudantów oraz konfiskowanie soli”. Senat zastrzegał dla siebie wydawanie patentów dla strażników wskazanych przez Kompanię, które mieli okazywać w trakcie podejmowanych czynności. Zasady ścigania defraudacji uzupełniono o postanowienie, że ich osądzenie powinno nastapić w terminie miesięcznym, „drogą najkrótszego procesu”. Skonfiskowana sól miała być zważona i zdeponowana w magazynie, do czasu wydania wyroku. Po jego ogłoszeniu połowę soli otrzymywał przedsiębiorca, połowę strażnik bądź denuncjator. Kary pieniężne pozostawiono bez zmian ${ }^{17}$.

Należy dodać, że o dzierżawę soli ubiegali się także liczni przedsiębiorcy krakowscy: spółka Piotra Steinkellera, Antoniego Morbitzera i Antoniego Holtzla, firma „Kirchmayer i Syn” (Wojciech Kirchmayer, Antoni Wentzel), a także Jan Librowski i Szymon Benda. Wymienieni przybyli nawet do biur senackich, chcąc zapoznać się z warunkami ogłoszonej licytacji ${ }^{18}$. Zgod-

${ }^{15}$ Ibidem, s. 91-92 (pismo Senatu Rządzącego do Wydziału Dochodów Publicznych, Biura Rachuby i entrepryzy sprzedaży soli z 16 sierpnia 1821, nr 2818). Również w umowie Austrii z Królestwem Polskim cena wynosiła 15 złp za cetnar.

${ }^{16}$ Ibidem, s. 677-707 (akt notarialny sporządzony przez Pisarza aktowego WMK, Antoniego Matakiewicza, z 24 stycznia 1820). Dokument składał się z 19 artykułów. Senat zatwierdził jego postanowienia 25 stycznia 1820, nr 243 Dziennika Głównego Senatu (dalej: DGS). Oprócz W. Kucieńskiego, B. Szmula Sonnenberga, S. S. Neumarka i G. Bereksohna, podpisali go również dwaj świadkowie: Baltazar Trzciński i Ferdynand Jaszke (Jaschke).

${ }^{17}$ Ibidem, s. 694-695 (akt notarialny z 24 stycznia 1820, art. 12-14, 15-16, 18-19). Zachowywały ważność konsensy wydane w okresie poprzedniej entrepryzy; nie wprowadzono ograniczeń ilościowych co do ilości przyznawanych zezwoleń; korespondencję między rządem a entreprenerami zwolniono od opłaty stemplowej. Por. „Zasady kontraktu do wydzierżawienia..." (par. XI-XII).

${ }^{18}$ Ibidem, s. 177 (pismo J. Librowskiego i S. Bendy do Senatu Rządzącego z 17 stycznia 1820); s. 179 (pismo spółki P. Steinkellera, A. Morbitzera i A. Holtzla do Senatu Rządzącego z 17 stycznia 1820); s. 181-182 (pismo W. Kirchmayera i A. Wentzla do Senatu Rządzącego z 17 stycznia 1820). Pisma zawierały skargi na brak konsultacji. 
nie z informacją opublikowaną w „Dzienniku Rządowym” nowa dzierżawa miała się rozpoczać 1 czerwca 1821 r. ${ }^{19}$ P. Steinkeller i A. Morbitzer oferowali zresztą Senatowi korzystniejsze warunki dzierżawy: tenutę zwiększoną o $30000 \mathrm{złp}$, znaczne obniżenie ceny detalicznej sprowadzanej soli, w zamian oczekując m.in. zgody na usytuowanie nad Przemszą dodatkowego składu solnego, a także wyjednania u władz austriackich zasad nabywania soli odpowiadających postanowieniom umów zawartych z Królestwem Polskim $^{20}$.

Pod naciskiem rządu Królestwa Senat odwołał jednak licytację. Co więcej, uznał za stosowne, by miejscowy monopol solny wydzierżawiać właśnie podmiotom korzystającym z niego w granicach Królestwa, czyli Kompanii Solnej. W przeciwnym razie rząd w Warszawie groził zaostrzeniem kontroli granicznej, a także pogorszeniem stosunków handlowych. Skupienie w ręku tego samego dzierżawcy zarówno transportu soli do magazynów w Królestwie, jak i administracji monopolu solnego na terytorium Rzeczypospolitej Krakowskiej miało za zadanie uniemożliwienie przemytu soli do Królestwa, uprawianego $\mathrm{z}$ powodu dużych różnic $\mathrm{w}$ cenach na obszarze obu państw. Chciano też położyć tamę powstającym $\mathrm{z}$ tego powodu rozruchom wśród ludności przygranicznejej ${ }^{21}$ O zaistniałej sytuacji i powodach swojej decyzji Senat powiadomił niedoszłych dzierżawców ${ }^{22}$.

Kompania Solna, która uzyskała przedłużenie kontraktu w znacznej mierze wskutek decyzji politycznych, przedstawiła wkrótce kandydatów na nowych strażników solnych. Rewizorem został Joel Jakub Goldberg, strażni-

${ }^{19}$ Obwieszczenie Senatu Rządzącego z 8 stycznia 1820, nr 59 DGS, Dziennik Rząowy Wolnego Miasta Krakowa i Jego Okręgu (dalej: Dz. Rząd. WMK) nr 2 z 8 stycznia 1820, s. 8.

${ }^{20}$ ANK, Archiwum Wolnego Miasta Krakowa, sygn. WMK V-115, s. 221-223 (deklaracja z 4 stycznia 1820). Zob. Jan Kosim, Losy pewnej fortuny: z dziejów burżuazji warszawskiej w latach 1807-1830, Wrocław 1972, s. 215-216.

${ }^{21}$ ANK, Archiwum Wolnego Miasta Krakowa, sygn. WMK V-115, s. 173-174 (pismo rezydenta Stanisława Zarzeckiego do Senatu Rządzącego z 12 stycznia 1820; pismo Senatu Rządzącego do S. Zarzeckiego z 18 stycznia 1820); s. 175-176 (pismo Komisji Rządowej Przychodów i Skarbu - Dyrekcji Dochodów Niestałych do S. Zarzeckiego z 12 stycznia 1820); J. Kosim, Losy pewnej..., s. 215; Szczęsny Wachholz, Rzeczpospolita Krakowska (okres od 1815 do 1830 r.), Warszawa 1957, s. 104-105.

22 ANK, Archiwum Wolnego Miasta Krakowa, sygn. WMK V-115, s. 183-184 (pismo Senatu Rządzącego z 20 stycznia 1821). Wedle zapewnień Senatu, powodem był wzgląd na „dobro Rzeczypospolitej”. 
kami zaś: Józef Sulikowski, Antoni Świdziński, Ludwik Judkowicz, Tomasz Zygmankowski (Zymantkowski), Jan Munch, Antoni Sulimiński i Franciszek Neustein. Patenty otrzymali oni 28 czerwca $1821 \mathrm{r}^{23} \mathrm{O}$ wydzierżawieniu monopolu poinformowano mieszkańców Krakowa ${ }^{24}$.

Zmiana dzierżawcy krakowskiego monopolu solnego nastapiła w 1822 r. Został nim wówczas rząd Królestwa Polskiego, z którym umowę podpisano 9 września 1821 r. Dzierżawa miała trwać 9 lat, do 31 maja 1832 r. Wysokość opłaty dzierżawnej wyznaczono na 195000 złp. Cenę soli ustalono na 15 złp za 1 cetnar miary berlińskiej. Po ratyfikacji przez oba rządy, umowa weszła w życie 1 czerwca $1822 \mathrm{r}^{25}$

Jej postanowienia nie odbiegały znacząco od warunków umowy z Kompanią Solną. Sprowadzanie najwyższej jakości soli miało się odbywać poprzez rogatkę I, po uiszczeniu rogatkowego i mostowego; utrzymano zakaz importu soli „na handel bądź prywatną potrzebę” z innych państw, pod groźbą kary pieniężnej (200 złp od cetnara) itd. „Administrację solną i straż od defraudacji” miał opłacać rząd Królestwa Polskiego. Jej urzędników („oficjalistów”) i strażników miano przedstawiać Senatowi, który wydawał zgody na pełnienie służby. Pod względem służbowym podlegali oni władzom w Warszawie, ,pod względem jurysdykcji” zaś Senatowi. Obowiązywały mundury z emblematami WMK. Utrzymano zobowiązanie udzielania Straży Solnej wszelkiej pomocy przez urzędników WMK itd. Zmianom nie uległ również zakres jej kompetencji ${ }^{26}$. Można dodać, że w związku z po-

${ }^{23}$ Ibidem, s. 93 (pismo entreprenera monopolu soli do Senatu Rządzącego z 24 kwietnia 1821, do nr 2221); s. 93 (pismo Senatu Rządzącego do entreprenera monopolu soli z 28 czerwca 1821, nr 2221).

${ }^{24}$ Obwieszczenie Wydziału Dochodów Publicznych z 31 maja 1821, nr 1763, Dz. Rzq̨. $W M K$, nr 18 z 2 czerwca 1821, s. 70. Magazyn Solny oraz Biuro Entrepryzy pozostały w dawnym miejscu. Wójtowie i ich zastępcy mieli powiadomić prowadzących „szynki solne".

${ }^{25}$ ANK, Archiwum Wolnego Miasta Krakowa, sygn. WMK V-115, s. 617 (pismo Senatu Rządzącego do Wydziału Dochodów Publicznych i Kasy Głównej z 30 października 1821, nr 4028). Zob. też ibidem, s. 613-614 (pismo Wydziału Dochodów Publicznych do Senatu Rządzącego z 28 października 1832, do nr 2598). Opłata dzierżawna była płatna comiesięcznie (po $16250 \mathrm{złp).}$

${ }^{26}$ Ibidem, s. 663-668 (kontrakt między pełnomocnikami Senatu Rządzącego i rządu Królestwa Polskiego z 9 września 1821). W razie braku pomocy ze strony urzędników, Senat miał wynagrodzić wynikłe z tego szkody, ,poszukując rekompensaty u winnych zaniedbania", stosując środki przymusu. Kontrakt liczył XXI artykułów, Straży Solnej poświęcono art. VIII-X. W imieniu Senatu podpisali go: Wojciech Kucieński, Mikołaj 
wyższą sytuacją Senat nakazał zwrócenie Kompanii Solnej kaucji 60000 złp, zdeponowanej w Kasie Głównej ${ }^{27}$.

Elementem realizacji umowy było obsadzenie poszczególnych stanowisk w Straży Solnej. Odbyło się to na wniosek Stanisława Jagielskiego, pełnomocnika rządu Królestwa Polskiego. Nadzorcą Straży Solnej ustanowiono Adolfa Kaniewskiego (były oficjalista w Królestwie Polskim), strażnikami pieszymi zostali: Wojciech Matłasiński (były kapral artylerii), Józef Szymanowski (były sierżant Wojska Polskiego), Jan Zwierzchowski oraz T. Zygmankowski. Rewizorem nadzorującym ,wolnych szynkarzy” został Stanisław Wyszomirski, były kapitan Wojska Polskiego. W Magazynie Solnym zatrudniono Stanisława Eigenfelda (pisarz) i Antoniego Gorzechowskiego (kontroler). S. Jagielski wystapił o wydanie rozporządzenia legitymującego ich działania na terytorium $\mathrm{WMK}^{28}$. Wkrótce Senat zapewnił o swobodzie poczynań Straży Solnej na podległym jego władzy terytorium, jak też udzielaniu jej wszelkiej pomocy, ,stosownie do trwających przepisów”. Nazwiska i stopnie jej funkcjonariuszy miano podać do publicznej wiadomości ${ }^{29}$.

W 1823 r. liczbę strażników zwiększono o czterech, „naprzeciwko granicy galicyjskiej”"30. W 1827 r. ,na własną prośbę” zwolniono rewizora Wyszomirskiego, powołując na jego miejsce Mikołaja Mieszkowskiego ${ }^{31}$.

Należy jeszcze zwrócić uwagę, że od korzystnego dla Królestwa Polskiego określenia warunków umowy dzierżawnej, minister Franciszek Ksawery Drucki-Lubecki uzależnił poczynienie ustępstw w przygotowywanym właśnie układzie handlowym z Rzeczpospolitą Krakowską. F. K. Drucki-Lu-

Hoszowski, Roman Markiewicz, Ludwik Sobolewski, w imieniu rządu Królestwa Polskiego - Stanisław Jagielski.

${ }^{27}$ Ibidem, s. 87-88 (pismo I. Neumarka do Senatu Rządzącego z 25 maja 1822); s. 8586 (pismo Senatu Rządzącego do Wydziału Dochodów Publicznych, Biura Rachuby i Kasy Głównej z 10 lipca 1822, nr 2455, nakaz zwrotu kaucji).

${ }^{28}$ Ibidem, s. 627-628 (pismo komisarza pełnomocnego rządu Królestwa Polskiego do Senatu Rządzącego z 4 czerwca 1822, nr 786). S. Jagielski posiadał stopień referendarza stanu Królestwa Polskiego.

${ }^{29}$ Ibidem, s. 628-629 (pismo Senatu Rządzącego do komisarza pełnomocnego rządu Królestwa Polskiego z 17 czerwca 1822, nr 2074). Ogłoszenie nominacji polecono Wydziałowi Dochodów Publicznych za pośrednictwem Dz. Rzad. WMK.

${ }^{30}$ Obwieszczenie Senatu Rządzącego z 3 października 1823, nr 3201, Dz. Rzqd. WMK, nr 31 z 18 października 1823, s. 133-134. Byli to: Jakub Gawłowski, Dominik Grabiński, Klemens Szczygielski i Jakub Goński.

${ }^{31}$ Obwieszczenie Senatu Rządzącego z 21 maja 1827, nr 2048, Dz. Rzą. WMK, nr 17 z 9 czerwca 1827, s. 65-66. 
becki oferował WMK ulgi w obrocie celnym, wyrażając zgodę na podwyższenie tenuty dzierżawnej, w stosunku do ustalonej w 1821 r., o dodatkowe 90 tys. złp rocznie, pod warunkiem sprowadzania soli po 21 złp za cetnar, co było dla mieszkańców WMK niekorzystne. Generalnie jednak, wynegocjowana umowa handlowa dotycząca „wolnego wprowadzania fabrykatów” z 7 sierpnia 1823 r. była dla krakowskiej republiki pomyślna. Ustalała taryfę celną dla pochodzących z WMK produktów surowych i przetworzonych, przy całkowitym zwolnieniu z cła wielu wyrobów. Również dla towarów obcych, których tranzyt przez obszar WMK był dokonywany za pośrednictwem kupców krakowskich, zagwarantowano pewne udogodnienia celne natury technicznej. Co najważniejsze, ulgi celne objęły najistotniejsze pozycje importu z Krakowa: drzewo, bydło, skóry, metale, a także wyroby galanteryjne. Układ obowiązywał do 1 czerwca 1832 r. Kontakty handlowe między obu krajami uległy intensyfikacjii2.

W 1832 r. w obliczu wygaśnięcia kontraktu sprzed 9 lat, Senat polecił Wydziałowi Dochodów Publicznych opracowanie nowej umowy, uwzględniającej blisko 10-letnie doświadczenia ${ }^{33}$. Doszło wtedy jedynie do jej jednorocznej prolongaty, wskutek braku szerszych pełnomocnictw dla S. Jagielskiego ${ }^{34}$.

Do odnowienia umowy handlowej z Królestwem Polskim doszło 1 lipca 1834 r. Pozostawiała ona $\mathrm{w}$ jego ręku monopol solny, $\mathrm{z}$ równoczesnym prawem bezcłowego wwożenia z WMK na terytorium Królestwa m.in. zboża, wina węgierskiego i drewna. Zarazem umowa handlowa nie była już dla Rzeczpospolitej tak korzystna, o czym zadecydowały głównie okoliczności natury politycznej. Obowiązywała do 31 maja $1843 \mathrm{r}^{35}$

Jeszcze w połowie $1842 \mathrm{r}$. odbyły się konsultacje rządowe, dotyczące prolongowania umowy dzierżawnej. Niebawem Senat ogłosił przedłużenie

${ }^{32}$ ANK, Archiwum Wolnego Miasta Krakowa, sygn. WMK V-115, s. 613-614 (pismo Wydziału Dochodów Publicznych do Senatu Rządzącego z 28 października 1832, do nr 2598); S. Wachholz, Rzeczpospolita Krakowska..., s. 104-105; J. Bieniarzówna, J. M. Małecki, Dzieje Krakowa..., s. 110-112.

${ }^{33}$ ANK, Archiwum Wolnego Miasta Krakowa, sygn. WMK V-115, s. 615 (pismo Senatu Rządzącego do Wydziału Dochodów Publicznych z 20 stycznia 1832, nr 252); s. 647, 656-657 (protokół posiedzenia Wydziału Dochodów Publicznych z 20 maja 1829).

${ }^{34}$ Ibidem, s. 613-614 (pismo Wydziału Dochodów Publicznych do Senatu Rządzącego z 28 października 1832, do nr 2598).

35 J. Bieniarzówna, J. M. Małecki, Dzieje Krakowa..., s. 112-113. 
umowy z 1834 r. o zaledwie jeden rok, do 31 maja $1843 \mathrm{r} .{ }^{36} \mathrm{~W}$ marcu $1843 \mathrm{r}$. pełnomocnik rządu Królestwa Polskiego oświadczył Senatowi, że prolongowana niedawno umowa dzierżawna nie zostanie przedłużona ${ }^{37}$. Dotyczyło to również układu handlowego. Pod naciskiem austriackim doszło więc do zerwania stosunków handlowych Rzeczypospolitej z Królestwem Polskim. Była to sytuacja dla krakowskich kupców wręcz dramatyczna, o czym świadczyły interwencje Kongregacji Kupieckiej, za wszelką cenę pragnącej utrzymania kontaktów handlowych z Królestwem Polskim ${ }^{38}$. Można nadmienić, że nie przyniosły pozytywnych rezultatów trzy konferencje międzyrządowe, zorganizowane w latach $1844-1845^{39}$. Traktat handlowy z cesarstwem austriackim podpisano $\mathrm{w}$ pierwszej połowie $1845 \mathrm{r}^{40}$

Po przyjęciu do wiadomości decyzji władz Królestwa Polskiego, Senat podjął szereg działań mających na celu określenie sytuacji m.in. na rynku obrotu solą ${ }^{41}$. Zgodnie z porozumieniem obu rządów, w Magazynie Solnym nie miały pozostać żadne zapasy, nakazano też sprawdzenie stanu zapasów soli u krakowskich szynkarzy ${ }^{42}$. Powyższe czynności zlecono Maciejowi Mączeńskiemu, komisarzowi handlowemu WMK (,komisarz wyrobów

${ }^{36}$ ANK, Archiwum Wolnego Miasta Krakowa, sygn. WMK V-151, s. 665-667 („Protokół konferencji międzyrządowej” z 8/20 lipca 1842); Obwieszczenie Senatu Rządzącego z 12 września 1842, nr 4849, Dz. Rzq̨. WMK, nr 106-109 z 1 października 1842, s. 424.

${ }^{37}$ ANK, Archiwum Wolnego Miasta Krakowa, sygn. WMK V-151, s. 535 (pismo komisarza pełnomocnego rządu Królestwa Polskiego do Senatu Rządzącego z 19/31 marca $1843 \mathrm{nr} 270)$.

${ }^{38}$ Ibidem, s. 941-942 (pismo Kongregacji Kupieckiej do Senatu Rządzącego z 9 marca 1843); s. 529-530 (pismo Kongregacji Kupieckiej do Senatu Rządzącego z 10 kwietnia 1843); s. 527-528 (pismo Kongregacji Kupieckiej do Senatu Rządzącego z 24 kwietnia 1843).

${ }^{39}$ Ibidem, s. 601-602 („,Protokół pierwszej konferencji w przedmiocie odnowienia układu o handel i sprzedaż soli z Rządem WMK” z 24 listopada 1844); s. 613-614 („Protokół drugiej konferencji...” z 11 grudnia 1844); s. 605-606 („Protokół trzeciej konferencji...” z 3 lutego 1845).

${ }^{40}$ Ibidem, s. 163-163 („Układ handlowy z Rządem Cesarsko-Austriackim zawarty” z 4 maja 1845, wersja polskojęzyczna); s. 299-305 (wersja niemieckojęzyczna).

${ }^{41}$ Ibidem, s. 935 (uchwała Senatu Rządzącego z 31 maja 1843, nr 1626, o ustaniu umowy z rządem Królestwa Polskiego); s. 921 (pismo komisarza pełnomocnego rządu Królestwa Polskiego do Senatu Rządzącego z 12 maja 1843); s. 921-922, 971 (pismo Senatu Rządzącego do Wydziału Dochodów Publicznych z 26 maja 1843, nr 143).

42 Ibidem, s. 921 (pismo komisarza pełnomocnego rządu Królestwa Polskiego do Senatu Rządzącego z 12 maja 1843); s. 921-922 i 971 (pismo Senatu Rządzącego do Wydziału Dochodów Publicznych z 26 maja 1843, nr 143). 
krajowych"), przydzielając mu do pomocy jednego z adiunktów Wydziału Dochodów Publicznych ${ }^{43}$.

Kontrakt na dostawy soli, podpisany w Wieliczce z rządem austriackim, miał obowiązywać przez 10 lat, od 1 czerwca 1842 do 31 maja 1852 r. Jej ilość określono na 20000 cetnarów miary wiedeńskiej rocznie. Cenę jednego cetnara ustalono na 53 krajcary. Co istotne, Senat zobowiązał się do zatrzymania monopolu solnego w swoim zarządzie, $\mathrm{z}$ wyłączeniem możliwości jego wydzierżawiania innym podmiotom. Sól nie mogła być sprzedawana taniej aniżeli 5 złr $33 \mathrm{kr}$. za 1 cetnar. Transport soli do granicy WMK miał się odbywać według przepisów austriackich, stąd obowiązywały „certyfikaty ładugowe", wydawane przez c.k. Urząd Ekspedycyjny, które okazywano w komorze celnej. Sól była zwolniona od cła wywozowego, stąd certyfikaty ładugowe i wywozowe miały być wydawane bezpłatnie. W uzasadnionych przypadkach Senat mógł zażądać zwiększenia dostaw do 40000 cetnarów, za uprzednim powiadomieniem Administracji Salinarnej o zwiększeniu zapotrzebowania. Rząd WMK zobowiązał się również do wyznaczenia urzędnika odpowiedzialnego za odbiór soli w Wieliczce, prowadzenie rachunkowości, współdziałanie z Administracją Salinarną itp. ${ }^{44}$

1 czerwca 1843 r. nastapiło zamknięcie komory celnej Królestwa Polskiego w WMK. Z tą datą sprzedaż soli przeszła w bezpośredni zarząd Wolnego Miasta Krakowa ${ }^{45}$. Spodziewając się takiego obrotu spraw, jeszcze

${ }^{43}$ Ibidem, s. 903 (pismo Wydziału Dochodów Publicznych do Senatu Rządzącego z 31 maja 1843, nr 2847); s. 903-904 (pismo Senatu Rządzącego do Wydziału Dochodów Publicznych i referenta Stanisława Paprockiego z 31 maja 1843, nr 2719). Urzędnicy informowali o trudnościach czynionych przez administrację w Wieliczce.

${ }^{44}$ Ibidem, s. 657-663 (kontrakt między administratorem Salin w Wieliczce, Franciszkiem hr. Orsini, oraz pełnomocnikiem rządu WMK Ludwikiem Sobolewskim z 19 marca 1842, do nr 1661 DGS). Opłata miała być wnoszona co kwartał do Administracji Salin Wielickich bądź do c.k. Centralnej Kasy Rządowej w Wiedniu. Senat zobowiązał się też do zapobiegania wszelkim nadużyciom ze strony firm transportowych (,frachciarze”), w tym ponownego wprowadzania zakupionej soli do innych prowincji Cesarstwa Austriackiego. Miał bezwzględnie egzekwować kary przewidziane za przestępstwa skarbowe (przeciwko Administracji Dochodów Niestałych). Kontrakt wszedł w życie po jego zaaprobowaniu przez rząd w Wiedniu (28 marca 1842).

${ }^{45}$ Wiktor Kopff, Zdanie sprawy o stanie i położeniu Kraju WMK i Jego Okręu w Zgromadzeniu Reprezentantów w 1844 r. przez Senatora do tegoż Zgromadzenia delegowanego, dodatek do Dziennika Praw WMK (dalej: Dz. Praw WMK) z 1844 r., s. 33-34; idem, Wspomnienia z ostatnich lat Rzeczypospolitej Krakowskiej, Biblioteka Krakowska nr 31, Kraków 1906, s. 44-45. 
w 1842 r. Senat zlecił adiunktowi Wydziału Dochodów Publicznych (senator Józef Kiełczewski) opracowanie projektu organizacji Administracji Solnej WMK. Zaproponował on powierzenie jej wszelkich czynności związanych z odbiorem soli z magazynu podgórskiego i jej rozprowadzaniem na obszarze WMK. Administracja miała również prowadzić rachunkowość, nadzorować sprzedaż detaliczną soli, zapobiegać jej przemytowi, kontrolować wagi używane w Magazynie Solnym oraz przez szynkarzy itp. Niezbędne było określenie liczby etatów oraz wysokości wynagrodzenia dla urzędników. Przez wzgląd na mnogość obowiązków planowanej instytucji, zwłaszcza zaś długość odcinka granicznego (nad brzegiem Wisły, od Igołomi do Chełmka), J. Kiełczewski zalecał przyjęcie do pracy jak największej liczby osób, mimo niewątpliwych kosztów. W jego ocenie, optymalne było zatrudnienie co najmniej 8 strażników wraz z kapralem. Na szefa Straży rekomendował M. Mączeńskiego ${ }^{46}$.

Za najlepszą lokalizację Magazynu Solnego J. Kiełczewski uznał położony na Stradomiu skład towarów komory Królestwa Polskiego, który z dniem 1 czerwca 1843 r. miał przejąć rząd Rzeczypospolitej Krakowskiej. Ze względu na zły stan techniczny budynku, J. Kiełczewski zasugerował jego wyremontowanie przez Oddział Budownictwa. Zachęcał do przekonywania pełnomocnika rządu Królestwa Polskiego, aby pozostawiono w składzie wagi z odważnikami. W przeciwnym razie niezbędne było ich dostarczenie przez Ekonomię Miejską. Konieczne było też „spisanie remanentów” przy udziale pełnomocnika S. Jagielskiego. W Okręgu mieli się tym zająć komisarze dystryktowi. J. Kiełczewski nalegał też na określenie zasad transportu soli z Wieliczki do Krakowa furmankami rządowymi bądź przez prywatnych dostawców wyłonionych w drodze przetargu. Szefowi Biura Rachuby należało powierzyć sporządzenie formularzy dla Kasy Głównej, ułatwiających kontrolę przychodów i rozchodów soli. W tej ostatniej miano się też posługiwać manuałem kasowym, dziennikiem kasowym oraz kwitariuszami, umożliwiającymi pokwitowanie odbioru soli. Jego propozycje

${ }^{46}$ ANK, Archiwum Wolnego Miasta Krakowa, sygn. WMK V-115, s. 951-960 (pismo Wydziału Dochodów Publicznych do Senatu Rządzącego z 30 kwietnia 1842, nr 1960); s. 951-952 (pismo Senatu Rządzącego do Wydziału Dochodów Publicznych z 5 kwietnia 1842, nr 1661). Poniesione wydatki miały zrekompensować zyski z udaremnionych defraudacji. J. Kiełczewski nadmienił, że w Królestwie Polskim Straż Solną tworzyli nadstrażnik oraz 12 strażników. Za stosowne uznał wyznaczenie M. Mączeńskiemu wynagrodzenia zbliżonego do dotychczasowej pensji. 
obejmowały też prowadzenie manuału magazynowego (dla Magazynu Solnego), w którym miano wpisywać ilość sprowadzonej soli, zgodnie z listami przewozowymi (tzw. frachtbriefami) z Podgórza. Pojawiła się też sugestia zaprowadzenia książeczek dla szynkarzy, w których kontroler wpisywałby ilość wydanej soli, a także podobnych książeczek dla strażników granicznych ${ }^{47}$.

Zaproponowane rozwiązania Senat przyjął 23 maja 1843 r. Zdecydował też o jak najszybszym uchwaleniu struktury Administracji Solnej oraz obsadzie poszczególnych stanowisk. Przed ich objęciem wymagano wpłacenia kaucji, która stanowiła zabezpieczenie ewentualnych strat wyrządzonych przez urzędników solnych ${ }^{48}$. Można dodać, że Senat nieźle orientował się w aktualnej sytuacji gospodarczej, w tym krokach podejmowanych przez „mocarstwa opiekuńcze”. W reakcji na posunięcie władz pruskich, które obniżyły cenę soli, rząd WMK uznał za konieczne zwiększenie liczby strażników, przewidując wzrost przemytu (,liczne defraudacje od tamtej strony") $)^{49}$.

Jako że adaptacja stradomskiego lokalu przedłużała się, Senat nakazał tymczasowe prolongowanie (z 6 miesięcy do 1 roku) kontraktu z Anną Malicka, która chwilowo wynajmowała lokal na potrzeby składu solnego. Ekonomii Miejskiej polecił sprawienie niezbędnego wyposażenia dla przyszłej siedziby Magazynu Solnego, w postaci 20 odważników oraz dwóch skrzyń do przechowywania dziennego utargu oraz do składowania 15-dniowych wpływów-depozytów ${ }^{50}$. Siedzibą Magazynu Solnego stał się wskazany w projekcie J. Kiełczewskiego gmach rządowy na Stradomiu (nr 25-28), w którym wcześniej mieścił się urząd celny oraz urząd pocztowy Królestwa

${ }^{47}$ Ibidem, s. 951-960 (pismo Wydziału Dochodów Publicznych do Senatu Rządzącego z 30 kwietnia 1842, nr 1960); s. 951-952 (pismo Senatu Rządzącego do Wydziału Dochodów Publicznych z 5 kwietnia 1842, nr 1661).

${ }^{48}$ Ibidem, s. 935-936 (uchwała Senatu Rządzącego z 21 maja 1843, nr 2541). Wprowadzenie w urzędowanie miało nastąpić do końca maja $1843 \mathrm{r}$.

${ }^{49}$ Ibidem, s. 938-939 (pismo Wydziału Dochodów Publicznych do Senatu Rządzącego z 2 maja 1843, nr 2244).

${ }^{50}$ Ibidem, s. 939-940, 965 (pismo Wydziału Dochodów Publicznych do Senatu Rządzącego z 2 maja 1843, nr 2244). Na pozostałe wyposażenie składały się: 3 stoliki, 4 kałamarze, 2 karafki na wodę, blaszana łopata do pieniędzy, gąbki, 3 ręczniki, 3 lichtarze, kilka miotełek itp. Ponadto: pieczęć Magazynu Solnego WMK z herbem państwowym, wózek do odwożenia pieniędzy oraz 30 worków na pieniądze. 
Polskiego, a także mieszkał rezydent rosyjski w Wolnym Mieście (baron Ernest Sternberg d'Ungern) ${ }^{51}$.

Senat polecił Księgarni Akademickiej wydrukowanie wzorów formularzy niezbędnych w pracy administracji solnej, jak też 300 książeczek dla szynkarzy solnych. Po oprawieniu przez sekretarza generalnego Senatu miały być udostępnione szynkarzom, w cenie 1 złp za sztukę. Rząd zatwierdził też spis wyposażenia Magazynu Solnego ${ }^{52}$. Dodatkowym niezbędnym wyposażeniem Magazynu Solnego okazały się przetaki do oczyszczania soli z drobin (,wysiewania grubych śmietków”), a także specjalne papierowe zasłonki do okien, które miały chronić wzrok pracowników Magazynu przed szkodliwym wpływem światła słonecznego odbijającego się w drobinach składowanej soli. Niezbędne były też kolejne ciężarki do wagi, dwie belki do podwieszenia wagi do ważenia soli, a także nowy okap „od zacieku wody deszczowej” nad bramą wejściową. Na wniosek Wydziału rząd wydał polecenia Ekonomii Miejskiej i Oddziałowi Budownictwa ${ }^{53}$.

${ }^{51}$ W. Kopff, Zdanie sprawy o stanie i położeniu Kraju WMK..., s. 53. W latach 18401842 budynek przeszedł poważniejszy remont. Na temat przeznaczenia budynku zob. ANK, Archiwum Wolnego Miasta Krakowa, sygn. WMK V-147, s. 1103 (pismo Rady Administracyjnej do Dyrektora Budownictwa i Ekonomii Miejskiej z 13 sierpnia 1846, nr 3831); sygn. WMK V-100, s. 429 (pismo Senatu Rządzącego do Wydziału Spraw Wewnętrznych z 18 lutego 1837, nr 923); s. 441 (pismo Inspektora Poczt Królestwa Polskiego do rezydenta rosyjskiego z 6 kwietnia 1846, do nr 1536); ANK, Akta fiskalne, sygn. 29/69/21, s. 143-302; sygn. 29/69/25, s. 1219-1438; Archiwum Wolnego Miasta Krakowa - Komitet Hipoteczny, sygn. Hip 4, s. 409-410; Danuta Rederow a, Studia nad wewnętrznymi dziejami Krakowa porozbiorowego (1796-1809), cz. 1: Zagadnienia urbanistyczne, Wrocław 1958, s. 149, 174.

${ }^{52}$ ANK, Archiwum Wolnego Miasta Krakowa, sygn. WMK V-115, s. 925-934 i 967 (pismo Senatu Rządzącego do Wydziału Dochodów Publicznych, komisarza pełnomocnego rządu Królestwa Polskiego, Ekonomii Miejskiej, Dyrekcji Policji, Komendanta Milicji, Księgarni Akademickiej, „Dziennika Rządowego” i „Gazety Krakowskiej” z 5 maja 1843); s. 923-924 (pismo Senatu Rządzącego do Wydziału Dochodów Publicznych z 9 maja 1843, nr 2371).

${ }^{53}$ Ibidem, s. 1581-1584 (pismo naczelnika Administracji Solnej do Wydziału Dochodów Publicznych z 13 września 1844, do nr 4639; pismo Wydziału Dochodów Publicznych do Senatu Rządzącego z 18 września 1844, nr 9021). Zasłonki miały też chronić sól przed promieniowaniem słonecznym. Powodem ich założenia było usytuowanie okien Magazynu w kierunku południowym i zachodnim. 
Wymiana okapu kosztowała 39 złp 23 gr $^{54}$. Nową belkę do podwieszania wagi zainstalował Ludwik Zieleniewski ${ }^{55}$. W miarę potrzeby prowadzono dalsze prace remontowe. Przykładowo, w 1846 r. okuto blachą drzwi prowadzące do kancelarii Magazynu, ponieważ dotychczasowe drzwi drewniane „nie stanowiły zupełnego bezpieczeństwa dla Kasy”. Niezbędne okazało się także wybrukowanie trotuaru przed budynkiem Magazynu, ze względu na poważne uszkodzenia spowodowane przez podjeżdżające ciężkie wozy z solą. Nad sąsiadującym z Magazynem rynsztokiem wystawiono dwa mostki ${ }^{56}$. O stanie budynków rząd był informowany przez naczelnika Administracji oraz Dyrektora Budownictwa ${ }^{57}$. Magazyn solny miał być pilnie strzeżony. Do jego pilnowania, na wzór rozwiązań w Królestwie Polskim, wyznaczono funkcjonariuszy Milicji Krajowej. Do rewizji szynkarzy władze WMK skierowały też komisarzy dystryktowych i cyrkułowych oraz urzędników Dyrekcji Policji ${ }^{58}$.

W świetle instrukcji dla naczelnika Administracji Magazynu Solnego w Krakowie, jej zadania obejmowały nadzór nad dostarczaniem do Krakowa zakontraktowanej soli, zapobieganie wszelkim nadużyciom, zwłaszcza defraudacjom solnym, a także „dokładna manipulacja pod względem kasowym i rachunkowym" (obsługa rachunkowa) dystrybucji soli ${ }^{59}$.

Nadzór nad urzędnikami Administracji Solnej sprawował jej naczelnik. Obejmował on w szczególności prawidłowe wykonywanie przez nich nałożonych obowiązków. Jego kontroli poddano też Magazyn Solny, w tym kasę magazynową. W drodze wizytacji naczelnik nadzorował funkcjonariuszy

${ }^{54}$ Ibidem, s. 1579 (pismo Wydziału Spraw Wewnętrznych do Senatu Rządzącego z 11 grudnia 1844, nr 6273). Pieniądze pochodziły z funduszu „na utrzymanie Gmachów Rządowych".

${ }^{55}$ Ibidem, s. 1577 (pismo Ekonomii Miejskiej do Wydziału Dochodów Publicznych z 6 grudnia 1844, nr 1171).

${ }^{56}$ Ibidem, s. 1573-1574 i 1591 (pismo Wydziału Dochodów Publicznych do Rady Administracyjnej z 19 sierpnia 1846, nr 3978).

${ }^{57}$ Ibidem, s. 87-88 (pismo naczelnika Administracji Solnej i Dyrektora Budownictwa do Wydziału Spraw Wewnętrznych z 24 lipca 1845, nr 1948).

${ }^{58}$ Ibidem, s. 964-965 (pismo Wydziału Dochodów Publicznych do Senatu Rządzącego z 2 maja 1843, nr 2244). Milicjantom miano zapewnić stancyjki, czyli pomieszczenia służące do odpoczynku po całonocnej służbie.

${ }^{59}$ Ibidem, s. 1165-1169 (rozporządzenie Senatu Rządzącego z 25 maja 1843, nr 2726 DGS, „Instrukcja dla Naczelnika Administracji Magazynu Solnego w Krakowie”, art. 1). Obowiązek zapoznania się z instrukcjami nałożono na wszystkich urzędników Administracji Solnej. 
solnych, rozmieszczonych w terenie. Mógł też przedkładać Senatowi wnioski dotyczące dyslokacji patroli Straży Solnej. Otrzymywał sprawozdania od dozorcy Straży Solnej dotyczące poczynań strażników solnych. Składał rządowi sprawozdania z działalności podległej sobie służby ${ }^{60}$.

Naczelnik osobiście, w godzinach porannych oraz po południu, miał asystować przy wydawaniu soli z Magazynu Solnego. Sprawdzał przy tym, aby nabywcy „nie doznawali przeszkód od urzędników”, którzy próbowaliby sprzedawać sól po zawyżonych cenach. Od powyższego obowiązku zwalniało go wizytowanie strażników bądź wyjazd po sól do magazynu w Podgórzu. Z punktu widzenia mieszkańców Krakowa oraz wsi okręgowych, ważne było dostarczanie do sprzedaży detalicznej soli należytej jakości. Stąd wprowadzenie kontroli u szynkarzy, którym zabroniono przechowywania soli w warunkach niegwarantujących jej czystości: zabronione było np. jej umyślne „mieszanie z piaskiem, ziemią, gipsem, lub mąką, dla pomnożenia miary albo wagi”. Karano też sprzedaż soli niepochodzącej z zapasów rządowych. Właściciele gospód, restauracji, traktierni itp. mieli też używać miar i wag obowiązujących w WMK, a także przestrzegać taksy rządowej na sprzedaż soli. Zobowiązano ich również do prowadzenia specjalnych książeczek, w których wpisywali ilość zakupionego towaru. Naruszenie powyższych obowiązków skutkowało, w ostateczności, utratą pozwolenia na handel solą oraz karami policyjnymi lub kryminalnymi ${ }^{61}$.

Na naczelniku spoczywały także obowiązki związane z cokwartalnym informowaniem Wydziału Dochodów Publicznych o zapotrzebowaniu na sól w Krakowie i Okręgu. Otrzymywał też od wydziału upoważnienie do poboru pieniędzy z Kasy Głównej, którymi płacił w Wieliczce za zakup soli. Tam wręczano mu asygnatę na sól wybranych gatunków: szybikową, zieloną i spiżową, którą naczelnik okazywał w magazynie podgórskim. Pokwitowanie dołączano do rachunku kwartalnego. Następnie sól załadowywano na wozy, wystawiając przy tym kartę przewozową ${ }^{62}$.

${ }^{60}$ Ibidem (art. 1, 4).

${ }^{61}$ Ibidem (art. 2-3). Każdy szynkarz mógł posiadać zapasy soli nie większe niż 60 cetnarów.

${ }^{62}$ Ibidem (art. 5-6). Opłata była wnoszona z góry, cokwartalnie, w gotówce, w siedzibie Administracji Salin Wielickich w Wieliczce. W karcie przewozowej znajdowały się dane personalne woźnicy (furmana), ilość wydanej soli, nr asygnacji, data sporządzenia. Wręczano ją furmanowi. Wozy stanowiły własność przedsiębiorcy transportowego, wybranego w licytacji. 
Naczelnik miał też dbać o przestrzeganie terminów zwrotu (w ciagu miesiąca od pobrania soli ze składu podgórskiego) tzw. certyfikatów ładunkowych („dowodów wychodowych”), które wydawał skład ekspedycyjny w Podgórzu. Były one poświadczane przez c.k. komorę celną graniczną, potwierdzając wywiezienie zakupionej soli za granicę; pilnował, aby tzw. procent bezpłatny (w istocie 12\%) z tytułu ubytków soli wydawanej przez rząd austriacki, uiszczano $\mathrm{w}$ naturze, $\mathrm{w}$ terminach określonych $\mathrm{w}$ umowie, przy okazji cokwartalnego płacenia rat umownych. Spoczywało na nim także: dokonywanie obrachunków z rządem austriackim z tytułu dostaw soli; kwitowanie jej odbioru, korespondencja z władzami; codzienne obliczanie gotówki zdeponowanej w skrzyni podręcznej, a następnie jej porównywanie z pokwitowaniami. W dalszej kolejności zaś składanie jej do skrzyni głównej, za której bezpieczeństwo ponosił współodpowiedzialność wraz z pisarzem Magazynu. Naczelnik mógł występować do Wydziału Dochodów Publicznych z wnioskami o ukaranie urzędników przekraczających swoje kompetencje ${ }^{63}$.

Istotne zadania wykonywał również pisarz Magazynu Solnego. Oprócz realizacji czynności zleconych przez naczelnika należało do niego utrzymywanie akt administracyjnych Magazynu w należytym porządku, prowadzenie dziennika podawczego oraz bieżącej rachunkowości (zapisywanie danych na tabliczkach, przy pomocy kredy), nadzór nad wagami i odważnikami. Ponosił też odpowiedzialność za przechowywaną w skrzyni głównej gotówkę, kontrasygnował pisma wychodzące z Administracji Solnej (wnioski i odpowiedzi). Za pośrednictwem jego oraz kontrolera miała być czyniona wszelka korespondencja urzędowa ${ }^{64}$.

Senat określił też zakres kompetencji dozorcy Straży Solnej, który również podlegał naczelnikowi. Podstawowym zadaniem dozorcy był nadzór nad strażnikami solnymi pełniącymi służbę w punktach granicznych. Odbywał się on poprzez comiesięczne, niezapowiedziane wizytacje, celem sprawdzenia, czy strażnicy ,nie oddają się pijaństwu, czy są czynnymi i czy

${ }^{63}$ Ibidem (art. 7-13). Co 15 dni gotówkę wpłacano do Kasy Głównej, w tym samym terminie Biuro Rachuby otrzymywało do skontrolowania wykazy (,ekstrakty”) gotówki oraz soli w naturze. Naczelnik mógł proponować wymiar kary dla urzędników solnych.

${ }^{64}$ ANK, Archiwum Wolnego Miasta Krakowa, sygn. WMK V-115, s. 1163-1164, $1173-$ 1174 (pismo Wydziału Dochodów Publicznych do Senatu Rządzącego z 31 maja 1843, nr 2744); s. 1174 („Instrukcja dla Pisarza i Kontrolera Magazynu Solnego w Krakowie” z 31 maja 1843). 
nie przestają z ludźmi podejrzanymi o defraudacje". Odbierał też od nich cotygodniowe raporty, które przesyłał naczelnikowi, ten zaś Wydziałowi Dochodów Publicznych ${ }^{65}$.

Bacznej obserwacji dozorcy podlegali szynkarze. W szczególności dotyczyło to zapobiegania sprzedaży soli o obniżonej wartości, spowodowanej jej zanieczyszczeniem; w razie stwierdzenia, że przepisy są łamane, sól podlegała konfiskacie, sprzedawcę miano odstawiać do najbliższego komisariatu dystryktowego. Czynności tych mógł dokonać osobiście dozorca, choć zasadniczo należały do strażników; przy konfiskacie mieli być obecni niezależni świadkowie, wskazani przez urząd gromadzki. Dozorca miał też zapobiegać zmowie między szynkarzami i właścicielami galarów spławiających sól Wisłą w chwili ich przybicia do brzegu; mieli też nie dopuścić do fikcyjnych kontroli w gospodach i karczmach. Kontrole szynkarzy w strefie nadgranicznej (do 1 mili od granicy) miały się odbywać co miesiąc, pozostałych co dwa miesiące. Należy dodać, że przemyt soli był zagrożony karami określonymi dla defraudacji: konfiskatą trefnego towaru oraz karami pieniężnymi (2 złp od 1 funta soli wagi berlińskiej), które przypadały, po połowie, Skarbowi Publicznemu oraz osobie donoszącej bądź strażnikowi. Władze WMK wprowadziły też zakaz importu soli ,na własne potrzeby": jej zakup był dopuszczalny wyłącznie w Magazynie Solnym bądź u licencjonowanych szynkarzy prowadzących książeczki szynkowe, „dla udowodnienia prawnego tejże nabywania" ${ }^{66}$. Rozporządzenie określało też wygląd służbowy dozorcy, który miał nosić granatową furażerkę z niebieską „obwódką manczesterową”, z oznakowaniem literami S.S. („Straż Solna”) oraz herbem WMK, odlanymi z mosiądzu i przyszytymi do czapki. Dozorca mógł nosić pałasz podobny do używanych przez żołnierzy kawalerii, który musiał jednak sprawić sobie własnym kosztem ${ }^{67}$.

Równie szczegółowa była instrukcja dla strażników solnych, stanowiących trzon Administracji Solnej w terenie. Ich podstawowym obowiazzkiem

${ }^{65}$ Ibidem, s. 1151-1153 (rozporządzenie Senatu Rządzącego z 27 maja 1843, nr 2726 DGS, „Instrukcja dla Dozorcy Straży Solnej Wolnego Miasta Krakowa”, art. 1, 5-7). Dozorca sporządzał też opinie o strażnikach, pośrednio dbając w ten sposób o dobrą opinię na swój temat.

${ }^{66}$ Ibidem (art. 3-4, 8-9, 10-11). W Magazynie solnym miano wydawać kupującym kwity sznurowe, będące dowodem legalnego nabycia soli.

${ }^{67}$ Ibidem (art. 12-13). W miarę potrzeby instrukcję miano uzupełnić dalszymi przepisami. Również szczegółowy wygląd munduru miano oznaczyć w późniejszym terminie. 
było zapobieganie przemytowi soli z państw ościennych, na patrolowanym przez nich w dzień i w nocy odcinku. Szczególnej uwadze strażników polecono załadunek soli na galary, ich przemieszczanie się wzdłuż wybrzeża Wisły, a także ewentualne przerwy w transporcie (,przybijanie na nocleg”). Można powiedzieć, że konwojowali statki z solą w granicach powierzonego rewiru, aż do momentu opuszczenia granicy Rzeczypospolitej Krakowskiej. W miejscach gdzie znajdowały się przeprawy (,,przewozy”) strażnicy pilnowali, aby podróżujący nie dopuszczali się nielegalnego przenoszenia bądź przewozu soli. Mogli dokonywać rewizji środków transportu, przy czym jedynie w przypadku donosu o przemycie kontrolowany mógł żądać ujawnienia nazwiska donoszącego. W razie zatrzymania przemytnika albo osoby sprzedającej sól bez zezwolenia Wydziału Dochodów Publicznych, towar miano zważyć lub ocenić na oko i odesłać do komisariatu dystryktowego (informacje mogły pochodzić od zwierzchnika gromadzkiego lub żandarmów), fakt zatrzymania odnotowywano w książeczce. W rozporządzeniu przewidziano również sytuacje, w których defraudacji dopuścili się cudzoziemcy: chcąc udać się w dalszą podróż, musieli wpłacić kaucję na poczet przyszłej kary, w wymiarze 2 złp za 1 cetnar soli, deklarując gotowość jej poniesienia. Strażnikom przykazano rozpoznawanie miejsc przemytu oraz ustalanie tożsamości osób dopuszczających się defraudacji. Szynkarze sprzedający sól oraz właściciele gospód, zajazdów itp. podlegali kontroli, czy nie mieszają soli z innymi substancjami; kontrola dotyczyła także zgodności posiadanej soli z odnotowaną w książeczkach, w związku z zakupem soli w krakowskim Magazynie Rządowym. W razie nieprawidłowości wzywano komisarza dystryktowego, który osobiście bądź za pośrednictwem adiunkta badał sprawę na miejscu; o zaistniałych faktach miał informować w raportach dozorcę. Jeżeli czynu dopuściła się osoba niebędąca szynkarzem, wówczas ustalano dane personalne (,stan zatrudnienia”, „stałe zamieszkanie” itp.) oraz miejsce zdeponowania skonfiskowanej soli. Na strażnikach spoczywało też prowadzenie dzienników czynności, w których odnotowywali ich przebieg. Były one co miesiąc przesyłane naczelnikowi, za pośrednictwem komisarzy dystryktowych. Bezpośrednim zwierzchnikiem strażników był dozorca, naczelnik zaś pośredniczył między nimi a wydziałami. Do wyżej wymienionych mieli się zwracać strażnicy, chcąc się „oddalić od obowiązków służbowych”, czy też w razie choroby. Aby jeszcze bardziej zmotywować strażników do zwalczania defraudacji, ustanowiono nagrodę pieniężną w wysokości połowy wartości skonfiskowanej soli (2 złp od każdego funta soli). W razie 
przeniesienia służbowego (,translokowania”), strażnicy mieli przekazywać swoim następcom wiedzę o notorycznych przemytnikach. „Dla wszelkiego bezpieczeństwa i odznaczenia się w służbie” strażnicy mogli nosić pałasz „na pendencie z ramienia wpuszczony”, z mosiężnym herbem państwowym na piersiach, sprawiany na własny koszt. W czynnościach służbowych obowiązywała ich grzeczność, ,zachowywanie jak najlepszej konduity”, a także unikanie pijaństwa; w przeciwnym razie nakładane były kary dyscyplinarne, w skrajnych przypadkach groziło im wydalenie ze służby ${ }^{68}$.

Pierwszych funkcjonariuszy Straży Solnej powołano w maju $1843 \mathrm{r}$. Jej szefem (naczelnikiem Administracji Solnej) został M. Mączeński (Mączyński), pisarzem Magazynu Onufry Orłowski, kontrolerem Augustyn Oraczewski, stróżem Jan Jaworski, posługaczem kancelaryjnym Błażej Niestruś ${ }^{69}$. W kolejnych miesiącach posady otrzymali ponadto: Wojciech Wilczyński (zastępca dozorcy Straży Solnej), Jan Nalepiński (zastępca stróża) oraz kilku strażników solnych (Władysław Gontzy, Tomasz Porębski, Andrzej Froncz, Władysław Hubert, Antoni Zamojski, Tomasz Wójcicki, Kajetan Olszewski, Antoni Wysocki, Antoni Wojeński, Józef Łyżwiński, Jan

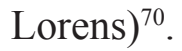

Ustalone w 1843 r. pensje dla pracowników Administracji Solnej były dość wysokie: naczelnik otrzymywał $3000 \mathrm{złp} \mathrm{rocznie,} \mathrm{pisarz} 2500 \mathrm{złp}$, kontroler 2000 złp (wkrótce zwiększona o 300 złp). Zarobki pozostałych urzędników były wyraźnie niższe: dozorca mógł liczyć na 500-600 złp rocznie, identyczne pieniądze otrzymywali starszy i młodszy stróż Magazynu

${ }^{68}$ ANK, Archiwum Wolnego Miasta Krakowa, sygn. WMK V-115, s. 1155-1160 (rozporządzenie Senatu Rządzącego z 27 maja 1843, nr 2726 DGS, „Instrukcja dla Strażników Solnych w kraju Wolnego Miasta Krakowa”). Instrukcja liczyła 16 artykułów. Strażnicy mieli dokładnie wykonywać polecenia przełożonych. W ściganiu obrotu solą pochodzącą z nielegalnych źródeł współdziałali ze zwierzchnikami gminnymi; w razie nieudowodnienia defraudacji, ale „dojścia do przekonania, że istotnie miała ona miejsce”, mieli zawiadamiać komisarzy dystryktowych.

${ }^{69}$ Zob. Obwieszczenie Senatu Rządzącego z 5 maja 1843, nr 2288, Dz. Rzad. WMK, nr 79-80 z 14 czerwca 1843, s. 316-317. O. Orłowski był wcześniej aplikantem Biura Rachuby, A. Oraczewski dziennikarzem (czyli prowadzącym dziennik podawczy) w Wydziale Dochodów Publicznych. Przysługiwało im prawo do pensji ,respective do ich posad przypisanych".

${ }^{70}$ Zob. Obwieszczenia Senatu Rządzącego z 30 maja 1843, nr 2702, Dz. Rzą. WMK, nr 81-82 z 21 czerwca 1843, s. 321-322; nr 3656 z 17 lipca 1843; nr 99-100 z 26 lipca 1843, s. 394; nr 6340 z 20 grudnia 1844; nr 168 z 31 grudnia 1844, s. 673. 
oraz posługacz kancelarii. Trzech strażników wyznaczonych do pilnowania granicy z Prusami zarabiało po 580 złp (razem kosztowali skarb 1740 złp), pozostali strażnicy po 480 złp (było ich 7, razem 3360 złp).W budżecie na lata 1845/1846 uwzględniono ponadto koszty wynajmu podwód dla naczelnika (500 złp), utrzymania konia i opłat dla dozorcy (400 złp), oświetlenia Magazynu i kancelarii (200 złp) oraz jej ogrzewania (160 złp). Utrzymanie Administracji Solnej kosztowało skarb WMK $16960 \mathrm{złp}^{71}$.

Należało też opłacić współpracującego z administracją Magazynu cymentiera (regulatora wag solnych) Józefa Weissa (Weise), który np. w 1845 r. skontrolował wszystkie wagi w Magazynie, wymieniając kilka odważników ${ }^{72}$.

Po przejęciu monopolu solnego we własny zarząd, Senat zawierał kontrakty na dostawy soli z magazynu podgórskiego z prywatnymi przedsiębiorcami, tzw. entreprenerami. W rezultacie ogłoszonego przetargu pierwszą umowę o przywóz soli zawarto z Majerem Alfusem³ ${ }^{73}$. Miała ona obowiązywać przez rok, do 31 maja $1844 \mathrm{r}^{74}$

Warto w tym miejscu poddać analizie najważniejsze postanowienia umowy podpisanej z M. Alfusem. Miał on „na każde wezwanie rządu” dostar-

${ }^{71}$ ANK, Archiwum Wolnego Miasta Krakowa, sygn. WMK V-115, s. 923-924 (pismo Senatu Rządzącego do Wydziału Dochodów Publicznych z 9 maja 1843, nr 2371); sygn. WM 21, s. 16-17 („Budget Rozchodów przez Izbę Reprezentacyjną w roku 1844 uchwalony”, „Budget w roku 1844 uchwalony do akt sejmowych należący”). Identyczne kwoty podano w: ibidem, s. 135 („Wykazy szczegółowe rozchodu do poszczególnych Tytułów budżetu z czerwca-lipca 1844 r. zaproponowane przez Komitet Skarbowy Zgromadzenia Reprezentantów").

${ }^{72}$ Ibidem, sygn. WMK V-115, s. 1571-1572 (pismo naczelnika Administracji Solnej do Wydziału Dochodów Publicznych z 16 września 1846, nr 72); s. 1575-1576 (pismo naczelnika do Wydziału Dochodów Publicznych z 27 lipca 1845, nr 40); s. 1567 (pismo naczelnika do Wydziału Dochodów Publicznych z 22 września 1846, nr 27); pismo Rady Administracyjnej do Wydziału Dochodów Publicznych, Biura Rachuby i Kasy Głównej z 18 września 1846, nr 4479; Deklaracja J. Weissa (na 30 złr) z 30 czerwca 1845, do nr 3001).

${ }^{73}$ Zob. ibidem, s. 911-914 (,Warunki do licytacji dostawy soli z Magazynu Cesarsko-Austriackiego w Podgórzu do Magazynu tutejszego Skarbu w Krakowie”, nr 2436 do nr 2665 DGS). Warunki zawierały 18 paragrafów. Senat Rządzący zatwierdził je decyzją z 19 maja 1843, nr 2526 DGS, ibidem, s. 915.

${ }^{74}$ Ibidem, s. 905 (pismo Senatu Rządzącego do Wydziału Dochodów Publicznych z 30 maja 1843, nr 2701); s. 905-906 (pismo Wydziału Dochodów Publicznych do Senatu Rządzącego z 29 maja 1843, nr 2797). 
czyć 30000 cetnarów soli (wagi wiedeńskiej), w cenie po 5 1/2 gr za cetnar. Miejscem dostawy był Magazyn Solny krakowski, tymczasowo mieszczący się w dawnym Arsenale Królewskim ${ }^{75}$, docelowo zaś w gmachu na Stradomiu. Koszty dostawy ponosił entreprener. Obejmowały one następujące czynności: ważenie soli i jej załadunek w Podgórzu, w dalszej kolejności przeładowanie soli na statki (celem przeprawienia się przez Wisłę) oraz rozładunek i załadowanie na wozy (fury), przy czym dopuszczono korzystanie maksymalnie z 6 wozów („pociągów”), o udźwigu 30 cetnarów każdy. Dostawy odbywały się za okazaniem tzw. frachtbriefu (karty przewozowej), co miało zapobiec pomyłkom; po dostarczeniu soli frachtbrief był zwracany przedsiębiorcy, który otrzymywał też pokwitowanie („,kwit sznurowy”) dostarczenia soli. Przedsiębiorcę zobowiązano do składania Wydziałowi Dochodów Publicznych ostemplowanej „likwidacji za dostawy", stanowiącej potwierdzenie kontroli i zatwierdzenia rachunków. Na jej podstawie, w ciagu 14 dni, wypłacano mu należność za dostarczony towar. Entreprener ponosił odpowiedzialność za ubytek soli (spowodowany jej ukruszeniem bądź ,utarciem się kruchów albo bałwanów”), którego stopień oceniał pisarz Magazynu Solnego. W tym przypadku przedsiębiorca mógł się odwołać do naczelnika, który decydował, czy do zwrotu kosztów utraconej soli pociagnąć furmana (otrzymywał on kontrakwit); w razie stwierdzenia, że osoby zatrudnione przy przewozie lub załadunku dopuściły się defraudacji, odpowiedzialność spoczywała na przedsiębiorcy; do niego należało też opłacanie rogatkowego, mostowego i przewozowego. Przedsiębiorca zobowiązywał się do ułatwiania wszelkich kontroli, nie ponosząc przy tym odpowiedzialności za szkody wywołane zgubieniem kart przewozowych; w razie niedostępności mostu na Wiśle (z powodu niemożności jego utrzymania ,przez właściwą administrację”) załadunek na galary miał się odbywać niedaleko Podgórza, sól miano spławiać do rogatki nr I. Przed podpisaniem umowy przedsiębiorca musiał wpłacić w Kasie Głównej kaucję 2000 złp w listach zastawnych Królestwa

${ }^{75} \mathrm{~W}$ budynku mieściła się m.in. Ekonomia Miejska, Administracja Okręgowa Kameralna oraz Urząd Celny. Zob. ibidem, sygn. WMK V-147, s. 1033-1034 (pismo Rady Administracyjnej do Komisji Gubernialnej z 16 kwietnia 1853, nr 5515 - przekazanie budynku Nadkomendzie Wojskowej). Obecnie jest to ostatni dom przy ul. Grodzkiej 64, Michał Rożek, Przewodnik po zabytkach i kulturze Krakowa, Warszawa 1993, s. 306-308. 
Polskiego. Z chwila jej uiszczenia zwracano mu wadium wpłacone przed licytacją ${ }^{76}$.

W 1844 r. M. Alfus zrezygnował z dalszej współpracy z Senatem, czego powodem był wzrost kosztów działalności, wywołany m.in. „podniesieniem się w cenie" najmu pracowników w związku z budową kolei żelaznej. W miejsce M. Alfusa wszedł Franciszek Dąbrowski ${ }^{77}$. Kontrakt podpisano z nim 21 maja $1844 \mathrm{r}^{78}$

W 1846 r. do walki o przedsiębiorstwo transportu soli, obok Dąbrowskiego, stanął mieszkający w Krakowie Franciszek Ripper. Rada Administracyjna ogłosiła przetarg, którego zasady były niemalże identyczne z warunkami ustalonymi w latach 1843-1845. Umowa miała obowiązywać od 1 czerwca 1845 do 31 maja 1846, odbiór soli miał się odbywać w Podgórzu itd. ${ }^{79}$ Złożone przez obu licytantów deklaracje zawierały zapewnienie o zdolności do wywiązania się z ,warunków przedsiębiorstwa”, potwierdzały też kwotę dostawy (po 6 gr za 1 cetnar) oraz wpłacenie wadium ${ }^{80}$.

Warto wspomnieć, że rachunki za dostawy soli były na bieżąco kontrolowane przez służbę rachunkową (Biuro Rachuby), a następnie zatwierdzane przez rząd. Odbywało się to w drodze tzw. likwidacji kosztów. Właściciele firm transportowych przedstawiali wnioski w przedmiocie wypłaty należności za swoje usługi, co miesiąc. W dokumentacji źródłowej zachowały się m.in. pisma F. Dąbrowskiego za czerwiec, wrzesień i grudzień 1846 r. oraz

${ }^{76}$ ANK, Archiwum Wolnego Miasta Krakowa, sygn. WMK V-115, s. 907-909 („,Kontrakt między Rządem WMK a Majerem Alfusem, przedsiębiorcą dostawy soli” z 29 maja 1843). W sprawach spornych przedsiębiorca poddawał się rozstrzygnięciom Wydziału Dochodów Publicznych i Senatu Rządzącego; pokrywał też koszty stempla. W Arsenale wcześniej znajdowały się stajnie dla koni Żandarmerii WMK.

${ }^{77}$ Ibidem, s. 1077 (pismo naczelnika Administracji Solnej do Wydziału Dochodów Publicznych z 27 kwietnia 1844, nr 67; Pismo Wydziału Dochodów Publicznych do Senatu Rządzącego z 1 maja 1844, nr 2205). F. Dąbrowski był właścicielem realności 8/9 w gm. VI.

${ }^{78}$ Ibidem, s. 1081-1087 („Kontrakt pomiędzy Rządem WMK i Franciszkiem Dąbrowskim") z 21 maja 1844. Jego postanowienia były zbliżone do obowiązujących w umowie z M. Alfusem. Entreprener miał przywozić 30000 cetnarów soli (wagi wiedeńskiej), za $51 / 2$ gr za cetnar itd.

${ }^{79}$ Ibidem, s. 1061-1064 (,Warunki o przedsiębiorstwo dostawy soli z Magazynu Podgórskiego do Krakowskiego" z 20 maja 1846). Rada Administracyjna zatwierdziła warunki 13 maja 1846, nr 2088.

${ }^{80}$ Ibidem, s. 1057 (deklaracja F. Rippera z 22 maja 1846); s. 1065 (deklaracja F. Dąbrowskiego z 22 maja 1846). Wadium określono na 2000 złp. 
luty $1847 \mathrm{r}^{81}$, a także cokwartalne sprawozdania z działalności Administracji Solnej ${ }^{82}$.

Wpływy ze sprzedaży soli w Rzeczypospolitej Krakowskiej były bardzo duże. Przykładowo, tylko w okresie lipiec-październik 1845 r. kupujący sól wpłacili do kasy magazynowej 155715 złp ${ }^{83}$, w okresie lipiec-październik 1846 r. 159978 złp $^{84}$, w okresie październik - grudzień 1846 r. zaś $189483 \mathrm{złp}^{85}$. Jeśli chodzi o wielkość dostaw, to tylko w lipcu 1844 r. było to 5600 cetnarów soli ${ }^{86}$. Wszelako, autor sprawozdania odczytanego na forum Zgromadzenia Reprezentantów w 1844 r. wyraził przekonanie, że utworzenie przez Senat własnej Administracji Solnej ,przyniosło duże korzyści dla Skarbu Publicznego" $" 87$.

Znaczenie dochodów z monopolu solnego dla finansów WMK pozwalają ustalić zachowane akta budżetowe z lat 1816-1845. Dla lepszego zobrazowania struktury poszczególnych ustaw budżetowych, dane ujęto w formie tabelarycznej ${ }^{88}$.

${ }^{81}$ Ibidem, s. 1025 (pisma F. Dąbrowskiego do Wydziału Dochodów Publicznych z 5 lipca 1846, do nr 3810, likwidacja za czerwiec 1846); s. 1023 (wrzesień 1846, z 29 września 1846, do nr 5959); s. 1021 (grudzień 1846, z 21 grudnia 1846, do nr 7670); s. 1019 (luty 1847, z 10 lutego 1847).

${ }^{82}$ Ibidem, s. 1229-1230, 1275-1277 (rachunki z działalności Administracji Solnej za I kwartał 1846); s. 1225-1226 i 1281-1283 (rachunki za II kwartał 1846); s. 1215-1219 (rachunki za III kwartał 1846); s. 1209-1214 (rachunki za IV kwartał 1846); s. 1201-1208 (rachunki za I kwartał 1847, wraz z ekstensja).

${ }^{83}$ Ibidem, s. 1243-1245 (pismo Rady Administracyjnej do Wydziału Dochodów Publicznych, Kasy Głównej i Administracji Magazynu Solnego z 5 maja 1846, nr 5639). Zob. przykładowe kwity: z 17 lipca 1845 (23 633 złp), z 1 sierpnia (17 833 złp), z 2 sierpnia (5 918 złp), z 18 sierpnia (23 625 złp), z 2 września (28 050 złp), z 17 września (29 673 złp), z 2 października (26 977 złp).

${ }^{84}$ Ibidem, s. 1215-1218 (pismo Rady Administracyjnej do Wydziału Dochodów Publicznych, Kasy Głównej i Administracji Magazynu Solnego z 22 kwietnia 1847, nr 1997).

${ }^{85}$ Ibidem, s. 1209-1211 (pismo Rady Administracyjnej do Wydziału Dochodów Publicznych, Kasy Głównej i Administracji Magazynu Solnego z 15 lipca 1847, nr 3822).

${ }^{86}$ Ibidem, s. 1043 (pismo F. Dąbrowskiego do Senatu Rządzącego z 27 czerwca 1844).

${ }^{87}$ W. Kopff, Zdanie sprawy o stanie i położeniu Kraju WMK..., s. 35-37.

${ }^{88}$ ANK, Archiwum Wolnego Miasta Krakowa, sygn. WM 16, s. 24,27 („Budget na Rok 1817/1818 co do Przychodu”, „Budgeta oryginalne Przychodów jako Rozchodów Wolnego Miasta Krakowa i Jego Okręgu z lat 1817/18-1826/27 przez Zgromadzenie Reprezentantów uchwalone”); s. 169, 172 („,Budget na Rok 1819/1820 co do Przychodu”); s. 284, 292 293 („Budget Przychodu na Rok 1820/21”); s. 680, 682-683 („Budżet Przychodów na Rok Etatowy 1822/23”); s. 814, 818-819 („Budget Przychodów na Rok Etatowy 1824/25”); 


\begin{tabular}{|c|c|c|c|c|c|c|c|c|c|}
\hline 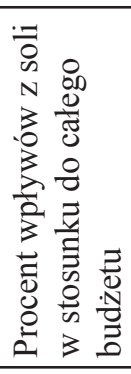 & $\begin{array}{l}\text { o̊ } \\
\text { oे } \\
\infty\end{array}$ & $\begin{array}{l}8^{\circ} \\
0 \\
0\end{array}$ & $\begin{array}{l}00 \\
0 \\
0\end{array}$ & ふे & $\begin{array}{l}\stackrel{0}{0}^{2} \\
\infty_{0}\end{array}$ & $\begin{array}{l}\stackrel{0}{\circ} \\
\stackrel{-}{-} \\
=\end{array}$ & $\begin{array}{l}0^{\circ} \\
0 \\
0 \\
0\end{array}$ & $\begin{array}{l}\stackrel{\text { N}}{2} \\
\text { กิ } \\
\infty\end{array}$ & $\begin{array}{l}\stackrel{0}{\Xi} \\
\overrightarrow{\vec{v}}\end{array}$ \\
\hline 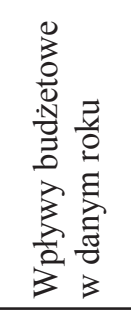 & $\begin{array}{l}\frac{2}{N} \\
2 \\
\infty \\
\sim \\
\infty \\
\sim \\
\\
-\end{array}$ & 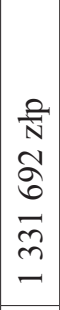 & $\begin{array}{l}\frac{2}{N} \\
\bar{n} \\
n \\
2 \\
\text { ñ } \\
-\end{array}$ & 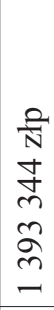 & $\begin{array}{l}\frac{2}{N} \\
0 \\
\infty \\
a \\
i n \\
i\end{array}$ & 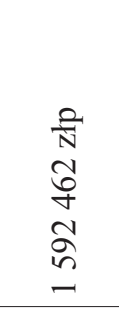 & $\begin{array}{l}\frac{2}{N} \\
0 \\
\frac{1}{2} \\
i \\
N \\
-1\end{array}$ & 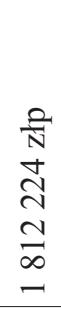 & 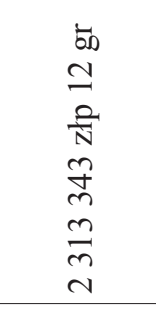 \\
\hline 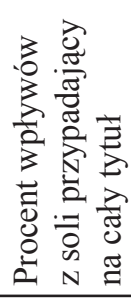 & $\frac{\stackrel{0}{a}}{\stackrel{a}{m}}$ & $\begin{array}{l}\text { o̊ } \\
\text { ปे } \\
\text { ปे }\end{array}$ & 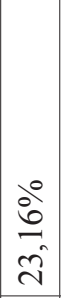 & 울 & $\begin{array}{l}\stackrel{0}{\hat{\sigma}} \\
\hat{\sigma} \\
\stackrel{+}{+}\end{array}$ & 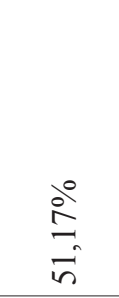 & $\underset{\text { fi }}{\stackrel{\infty}{+}}$ & $\begin{array}{l}\stackrel{0}{\infty} \\
\text { in } \\
\text { ஸn }\end{array}$ & $\begin{array}{l}\partial^{0} \\
i n \\
\hat{n}^{2}\end{array}$ \\
\hline 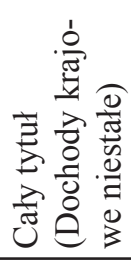 & \begin{tabular}{l}
$\frac{2}{N}$ \\
$\infty$ \\
0 \\
0 \\
0 \\
\multirow{2}{n}{}
\end{tabular} & $\begin{array}{l}\frac{e}{N} \\
o \\
a \\
\sim \\
\text { v }\end{array}$ & $\begin{array}{l}\frac{2}{N} \\
2 \\
2 \\
0 \\
\infty \\
n\end{array}$ & $\begin{array}{l}\frac{2}{N} \\
0 \\
\text { nू } \\
\text { Dे } \\
\text { ñ }\end{array}$ & $\begin{array}{l}\frac{2}{N} \\
\text { ڤn} \\
n \\
n \\
\hat{\sigma}\end{array}$ & $\begin{array}{l}\frac{a}{N} \\
\frac{a}{a} \\
b \\
i n\end{array}$ & $\begin{array}{l}\frac{2}{N} \\
0 \\
= \\
\infty \\
0\end{array}$ & $\begin{array}{l}\frac{2}{N} \\
\infty \\
0 \\
\infty \\
\infty \\
\infty\end{array}$ & $\begin{array}{l}\frac{0}{N} \\
n \\
\vdots \\
+ \\
\exists \\
\pm \\
-1\end{array}$ \\
\hline 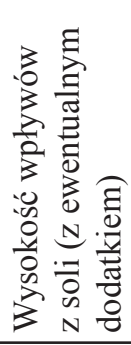 & $\begin{array}{l}\frac{2}{N} \\
8 \\
8 \\
0 \\
=\end{array}$ & $\begin{array}{l}\frac{0}{N} \\
0 \\
8 \\
0 \\
0 \\
\text { ר }\end{array}$ & $\begin{array}{l}\frac{2}{N} \\
0 \\
8 \\
0 \\
0 \\
\text { ㄱ }\end{array}$ & $\begin{array}{l}\frac{2}{N} \\
8 \\
8 \\
n \\
2\end{array}$ & 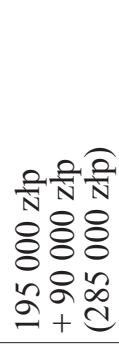 & 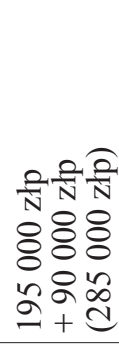 & 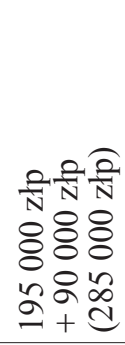 & $\begin{array}{l}\frac{2}{N} \\
8 \\
8 \\
\text { N } \\
\text { ñ }\end{array}$ & 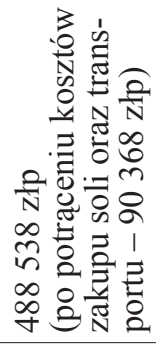 \\
\hline $\begin{array}{l}\stackrel{\vec{N}}{:} \\
\stackrel{\vec{v}}{\vec{D}} \\
\stackrel{0}{n}\end{array}$ & $\begin{array}{l}\frac{\infty}{\infty} \\
\bar{\equiv} \\
\infty \\
=\end{array}$ & 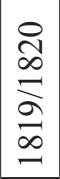 & 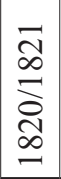 & $\begin{array}{l}\underset{N}{\infty} \\
\underset{\Sigma}{\tilde{N}} \\
\infty \\
-1\end{array}$ & 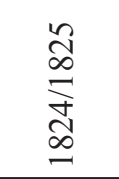 & 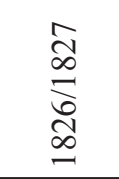 & $\frac{\hat{m}}{\infty} \underset{\infty}{\infty}$ & $\begin{array}{l}\vec{J} \\
\underset{\infty}{\infty} \\
\infty \\
\infty \\
\infty\end{array}$ & $\frac{0}{+}$ \\
\hline
\end{tabular}


Parę słów poświęcić należy sposobom zwalczania przemytu soli oraz innych rodzajów „defraudacji”. W tym przedmiocie w WMK obowiązywały początkowo regulacje z czasów Księstwa Warszawskiego (Kraków był „stolicą" jednego z departamentów Księstwa) ${ }^{89}$. Uchwała Senatu z 1818 r. utrzymywała je również w zakresie „kupowania i sprzedawania soli”. W związku z tym, aby legalnie handlować solą, należało legitymować się zezwoleniem (konsensem) wystawionym przez Wydział Dochodów Publicznych. Zabroniono roznoszenia soli po domach, gdyż handel nią mógł się odbywać wyłącznie w wyznaczonych punktach. Niedozwolone było też ,podwożenie lub podnoszenie soli” przez szynkarzy na jarmarkach, targach, odpustach, gdyż uniemożliwiałoby to skuteczną kontrolę. Sprzedaż soli w Okręgu Krakowskim miano organizować zasadniczo w miejscowościach, w których był kościół bądź klasztor, przy czym celem „zrobienia dogodności dla kupujących" tymczasowo zezwolono na to również w pozostałych wsiach, pod warunkiem posiadania konsensu. Sądzenie spraw defraudacyjnych należało do wójtów okręgowych ${ }^{90}$.

s. 927, 933 („Budget Przychodów na Rok Etatowy 1826/27”); sygn. WM 20, s. 112-113, 116-117 („Budget Przychodów na Rok 1833/37”, „Budgeta oryginalne Przychodów jako Rozchodów WMK i Jego Okręgu z lat 1833/37-1838/41 przez Zgromadzenie Reprezentantów uchwalone”); s. 486-487, 500-501 („Budget Przychodu na Rok 1838/41 czyli na czas od dnia 1 Czerwca 1838 do ostatniego Grudnia 1841 roku”); sygn. WM 21, s. 27 („Budget Przychodu uchwalony przez Zgromadzenie Reprezentantów WMK i Jego Okręgu na posiedzeniu w dniu 13 lipca 1844 r.”, „Budget w roku 1844 uchwalony do akt Seymowych należący”); s. 31-32 („Uwagi nad Budgetem Przychodu uchwalone przez Zgromadzenie Reprezentantów na posiedzeniu w dniu 13 lipca 1844 r.”); Ustawa z 9 stycznia $1821 \mathrm{Bu}$ dżet na r. 1821/1822, ogłoszona pismem Senatu Rządzącego nr 183 DGS, Dziennik Rozporzqdzeń Rzadowych Wolnego, Niepodległego i Ściśle Neutralnego Miasta Krakowa i jego Okręgu (dalej: Dz. Rozp. Rząd.) z 1821 r.

${ }^{89}$ Były to: ANK, Archiwum Wolnego Miasta Krakowa, sygn. WMK V-115, s. 791-803 (Urządzenie Ministra Skarbu z 1 października 1809, „Zbiór przepisów i ustaw dotąd zachowanych dla administracji skarbowej, a działaniom ich za prawidło służyć mających”). Spraw solnych dotyczył tytuł VIII „O Soli” (art. 84). Ponadto, ibidem, s. 807-819 (instrukcja Ministra Skarbu z 20 listopada 1809, „Instrukcja dla Komór Celnych i Konsumpcyjnych Księstwa Warszawskiego, jak sobie przy odkryciu kontrabandy postępować mają"). Zob. ibidem, s. 786 (notatka referenta Wydziału Dochodów Publicznych z 14 lipca 1832, do nr 3961). Stwierdził on, że urzędy „miały one doręczone w książeczkach drukowanych”. Regulacje powyższe obowiązywały też w Królestwie Polskim.

90 Obwieszczenie Wydziału Dochodów Publicznych z 28 października 1818, nr 5363, Dz. Rzą. WMK, nr 41 z 7 listopada 1818, s. 171-172; Uchwała Senatu Rządzą- 
Przyjęta w 1820 r. ustawa „O sądzeniu spraw defraudacyjnych” dotyczyła przemytu soli jedynie w pewnym zakresie ${ }^{91}$. Dlatego Senat wystapił do pełnomocnika Jagielskiego o udostępnienie ,regulaminu solnego” obowiązującego w Królestwie Polskim. Miało to ułatwić opracowanie projektu „urządzeń skarbowych, co do postępowania w podobnych procesach"92. W 1825 r. Senat przypomniał wójtom, że prawo zamiany kary orzeczonej za defraudacje solne z pieniężnej na areszt lub chłostę, należało wyłącznie do władzy sądowej (Trybunał I Instancji), na wniosek Wydziału Dochodów Publicznych ${ }^{93}$.

Ustawę defraudacyjną z 1820 r. zmodyfikowano w 1838 r. Przemyt towarów akcyzowych wyłączono spod jurysdykcji sądów na rzecz władz administracyjnych. Rozpoznawaniem (,,instruowaniem”) spraw defraudacyjnych miał się zajmować Urząd Konsumpcyjny. Wyroki w I instancji wydawała Dyrekcja Policji, w II instancji - Wydział Dochodów Publicznych. Skazany mógł się odwołać (,w drodze łaski”) do Senatu, którego orzeczenie było ostateczne $^{94}$. Można wspomnieć, że umowa z Królestwem z 1834 r. pierwotnie przekazywała sądzenie defraudacji solnych sądom podsędkowskim, jednak ostatecznie pozostały one w gestii sądów wójtowskich ${ }^{95}$.

cego z 10 października 1818, nr 3202. W ogłoszeniu wspomniano o wyposażonej w pałasze Straży Solnej, której funkcjonariusze legitymowali się rządowymi zezwoleniami.

${ }^{91}$ Ustawa z 7 stycznia 1820 O sqdzeniu spraw defraudacyjnych, ogłoszona pismem Senatu Rządzącego z 10 stycznia 1820, nr 78 DGS, Dz. Rozp. Rzq̨d. z 1820 r. Sądzenie spraw defraudacyjnych powierzono organom administracji, z możliwością odwołania się do sądu powszechnego. Do przemytu soli stosowano m.in. art. 6-7. Egzekwowanie kar pieniężnych powierzono sekwestratorom oraz komornikom sądowym.

${ }^{92}$ ANK, Archiwum Wolnego Miasta Krakowa, sygn. WMK V-115, s. 785 (pismo Senatu Rządzącego do komisarza pełnomocnego rządu Królestwa Polskiego z 13 sierpnia 1824, nr 2992; pismo komisarza pełnomocnego do Senatu Rządzącego z 8 października 1824, nr 3961).

${ }^{93}$ Obwieszczenie Wydziału Dochodów Publicznych z 25 października 1825, nr 4900, Dz. Rzad. WMK, nr 40 z 12 listopada 1825, s. 168; Uchwała Senatu Rządzącego z 12 września 1825, nr 3900.

${ }^{94}$ Rozporządzenie Senatu Rządzącego z 20 kwietnia 1838, nr 1882, Przepisy o instruowaniu i decydowaniu spraw defraudacyjnych, Dziennik Praw WMK z 1838 r. Odwołanie do Senatu należało wnieść w terminie 14-dniowym. Kara pieniężna mogła zostać zamieniona na chłostę lub areszt.

${ }^{95}$ Obwieszczenie Senatu Rządzącego z 19 maja 1835, nr 2537, Dz. Rzad. WMK, nr 24 z 13 czerwca 1835, s. 93-94; pismo komisarza pełnomocnego rządu Królestwa Polskiego do Senatu Rządzącego z 29 kwietnia 1835, nr 296. 
Postępowania karno-skarbowe przeciwko defraudantom solnym zdarzały się dość często. Za przykład posłużyć może sprawa wyrobnika z Galicji Antoniego Dziuba, którego w 1829 r. wójt krakowskiej gminy VII skazał na karę 66 złp za przemyt 33 funtów soli. Doszło także do konfiskaty towaru. Skazany wniósł odwołanie („rekurs”) do Wydziału Dochodów Publicznych ${ }^{96}$. Inną sprawę stanowi wcześniejszy o kilka lat przypadek Gabriela Strzeleckiego z Podgórza, obwinionego o przemyt 17 funtów soli (wagi berlińskiej) oraz Anny Kulczyckiej, która dopuściła się defraudacji w identycznym wymiarze. Pochwycenia dokonał strażnik Szymanowski. W sprawie orzeczono przepadek zatrzymanego towaru, przy czym Senat, ze względu na ubóstwo oskarżonych, umorzył połowę kary pieniężnej (34 złp) ${ }^{97}$.

Dochodziło również do innych nieprawidłowości w wykonywaniu umów dzierżawnych. W 1835 r. Senat otrzymał informację o stwierdzonych przypadkach odstępowania przez właścicieli dóbr ziemskich soli zakupionej na własne potrzeby, na rzecz karczmarzy prowadzących wyszynk w granicach ich posiadłości. Ponieważ powodowało to straty w skarbie Królestwa Polskiego, na żądanie jego władz Senat nakazał wójtom wydawanie świadectw na zakup soli w Magazynie jedynie w wymiarze faktycznie niezbędnym dla własnych potrzeb, czy to właścicieli ziemskich, dzierżawców, proboszczów itp. Osoby odsprzedające sól miały być traktowane jak defraudanci. Szynkarze mieli informować Straż Solną o przypadkach cząstkowej sprzedaży soli bez konsensu ${ }^{98}$.

Administracja Solna działała w wyżej zarysowanym kształcie jedynie przez kilkanaście miesięcy. W związku z włączeniem Rzeczypospolitej Krakowskiej do cesarstwa austriackiego (16 grudnia 1846 r.) nastapiła stopniowa likwidacja wszelkich odrębności prawnych miniaturowej republiki. Zmiany dotknęły także Administrację Solną. Pod koniec listopada 1846 r.

${ }^{96}$ ANK, Archiwum Wolnego Miasta Krakowa, sygn. WMK V-115, s. 719 (pismo komisarza pełnomocnego rządu Królestwa Polskiego do Senatu Rządzącego z 30 października 1829, nr 409, do nr 5020); s. 723 (pismo Wydziału Dochodów Publicznych do Senatu Rządzącego z 13 listopada 1829, nr 3880).

${ }^{97}$ Ibidem, s. 767-768 (pismo Senatu Rządzącego do Wydziału Dochodów Publicznych z 13 sierpnia 1824, nr 2992; pismo Wydziału Dochodów Publicznych do Senatu Rządzącego z 30 kwietnia 1824, nr 979). Senat zastrzegł, że w razie niezapłacenia reszty kary skazani zostaną osadzeni w areszcie policyjnym.

98 Obwieszczenie Senatu Rządzącego z 27 stycznia 1835, nr 3487/1834, Dz. Rząd. $W M K$, nr 4-5 z 7 lutego 1835, s. 13-14. Przestrzeganie powyższych przepisów powierzono w szczególności wójtom. 
Komisarz Nadworny (hr. Maurycy Deym) poinformował Radę Administracyjną, że Administracja Solna ma odtąd pozostawać pod zwierzchnictwem Administracji Okręgowej Kameralnej, z zastrzeżeniem, iż w kwestii rozliczania dostaw soli będą stosowane dotychczasowe przepisy i zarządzenia, w tym zasady rachunkowości (tzw. manipulacji) ${ }^{99}$.

W 1847 r. Austriacy wprowadzili własny monopol solny. Odtąd handel solą był możliwy jedynie za pośrednictwem rządowych składów solnych, będących punktami handlowymi upoważnionymi do sprzedaży soli po z góry ustalonych cenach ${ }^{100}$. Władze austriackie rozpoczęły przenoszenie urzędników Administracji Solnej do innych instytucji (np. urzędów rogatkowych), aby w końcu oddalić ich ze służby publicznej. W związku z tym występowali oni o wykreślenie (ekstabulację) z akt hipotecznych kaucji wpłaconej przy obejmowaniu stanowiska ${ }^{101}$.

Magazyn Solny zakończył działalność 1 kwietnia 1847 r. Rada Administracyjna starała się znaleźć pracę jego zwalnianym stróżom, z ,pozostawieniem ich przy dotychczasowych pensjach"102. Przeprowadziła tzw. absolwowanie rachunków, które potwierdziło poprawność i zgodność rozliczeń likwidowanej Administracji Solnej ${ }^{103}$. Ponadto wykonywała polecenia

${ }^{99}$ ANK, Archiwum Wolnego Miasta Krakowa, sygn. WMK V-5, s. 879 (pismo Komisarza Nadwornego do Rady Administracyjnej z 28 listopada 1846, nr 38); s. 879-880 (pismo Rady Administracyjnej do Wydziału Dochodów Publicznych i naczelnika Administracji Solnej z 1 grudnia 1846, nr 5753, zawiadomienie o piśmie).

${ }^{100}$ Obwieszczenie Komisarza Nadwornego z 27 stycznia 1847, Zaprowadzenie monopolu soli na terytorium Krakowa i obwieszczenie sposobów i ceny sprzedaży soli, Dziennik Rzadowy Miasta Krakowa i Jego Okręgu z 29 kwietnia 1847, nr 68-73, s. 269-277 (to samo w: Provinzial Gesetzsammlungdes königreiches Galizien und Lodomerien für das Jahr 1847, R. 29, s. 45-47).

${ }^{101}$ ANK, Archiwum Wolnego Miasta Krakowa, sygn. WMK V-115, s. 1197-1198 (pismo O. Orłowskiego do Rady Administracyjnej z 18 marca 1851, wniosek o wykreślenie 2500 złp, zabezpieczonych na kamienicy nr 8/9 w gm. VI); s. 1195 (pismo A. Oraczewskiego do Rady Administracyjnej z 3 kwietnia 1851, wniosek o wykreślenie 2000 złp, zabezpieczonych na kamienicy nr $78 \mathrm{w}$ gm. VII).

${ }^{102}$ Ibidem, sygn. WMK III-45 C, s. 2655 (pismo Rady Administracyjnej do Prezydium Rady Administracyjnej z 26 marca 1847, nr 1574; pismo naczelnika Administracji Solnej do Rady Administracyjnej z 18 marca 1847, nr 7). B. Niestrusia i Mateusza Małodobrego skierowano do Dyrekcji Policji, J. Lorens został stróżem jatek rzeźniczych, ibidem, sygn. WMK V-10, s. 641, 657 (,Rewersy na akta wydane z Archiwum” z 1847).

${ }^{103}$ Ibidem, sygn. WMK V-115, s. 1195 (pismo Rady Administracyjnej z 31 grudnia 1847, nr 7601, udzielenie absolutorium na złożone rachunki dostaw soli). 
władz austriackich, związane z przekazaniem kopalni i hut rządowych w zarząd Administracji Salinarnej w Wieliczce ${ }^{104}$.

Sumując powyższe rozważania, należy stwierdzić, że formy organizacyjne korzystania z monopolu solnego przez władze Rzeczypospolitej Krakowskiej były dwojakie. W latach 1815-1822 dostawy soli i obrót nią wydzierżawiano Kompanii Solnej. Następnie, przez kilkanaście lat, obowiązywały podobne umowy, podpisywane z rządem Królestwa Polskiego. W połowie lat 40. XIX w., w związku ze zmieniającą się sytuacją polityczną i gospodarczą, powyższe zadania przejęła bezpośrednio administracja rządowa WMK. Dostawy soli z Podgórza do Krakowa zlecano wówczas prywatnym przedsiębiorcom transportowym. Urzędnicy Administracji Solnej ponosili odpowiedzialność za należyte zaopatrzenie Magazynu Solnego, sprawowali nadzór nad przestrzeganiem zasad monopolu solnego, odpowiadali za prawidłowy obieg dokumentów, rozliczenia finansowe itd. Podlegająca Administracji Solnej Straż Solna miała zapobiegać przemytowi soli oraz wszelkim nadużyciom w handlu detalicznym. Straż współdziałała z aparatem policyjnym oraz administracją skarbową WMK (Milicja Krajowa, strażnicy rogatkowi, wójtowie, komisarze dystryktowi, Dyrekcja Policji, Urząd Konsumpcyjny). W latach 1816-1842 działalność Straży Solnej finansowali dzierżawcy monopolu solnego, mający przy tym wpływ na jej obsadę personalną. Ustalenia zaprezentowane $\mathrm{w}$ powyższym artykule, choć dotyczą niewielkiego wycinka działalności władz WMK, stanowią uzupełnienie wiedzy z zakresu handlu solą na ziemiach polskich w XIX w.

\section{BIBLIOGRAFIA}

\section{Źródla rękopiśmienne}

Archiwum Narodowe w Krakowie

Akta fiskalne, sygn. 29/69/21, 29/69/25.

Archiwum Wolnego Miasta Krakowa, sygn. Hip 4, WM 16, 20, 21, WMKIII-45 C, WMK V-5, WMK V-10, WMK V-100, WMK V-115, WMK V-147, WMK V-151, WMK V-494.

Zbiór kartograficzny, sygn. I-36, II-29.

${ }^{104}$ Ibidem, sygn. WMK V-494, s. 420 („Dziennik Główny Senatu Rządzącego WMK”, pismo referendarza W. Wolffa do Rady Administracyjnej z 22 grudnia 1847, do nr 7389). Sprawę odłożono ad acta 31 grudnia 1847. Przekazano jej również lasy skarbowe oraz majątek należący do ekonomii jaworznickiej, prądnickiej i czernichowskiej. 


\section{Źródla drukowane}

Kalendarzyk polityczny krakowski na rok 1844. Kraków: nakładem J. Cypcera, 1844.

Kalendarzyk polityczny krakowski na rok 1846. Kraków: Drukarnia Stanisława Gieszkowskiego, 1846.

\section{Druki urzędowe}

Dziennik Praw Wolnego Miasta Krakowa. Kraków: Drukarnia S. Gieszkowskiego, 1838.

Dziennik Rozporzadzeń Rzadowych Wolnego Niepodległego i Ściśle Neutralnego Miasta Krakowa i jego Okręgu. Kraków: Drukarnia J.A. Maya, 1820, 1821.

Dziennik Rzadowy Miasta Krakowa i Jego Okręgu. Kraków: Biuro Kommissaryjatu Targowego, 1847.

Dziennik Rzqdowy Wolnego Miasta Krakowa i Jego Okręgu. Kraków: Drukarnia J.A. Maya, 1818, 1820-1821, 1823, 1825, 1827, 1835, 1842-1844.

Provinzial Gesetzsammlung des königreiches Galizien und Lodomerien für das Jahr 1847, R. 29. Lwów: Galicyjska Drukarnia Rządowa (k. k. Galizischen Aerarial Drucekren), 1852.

\section{Opracowania}

Atlas Historyczny Miast Polskich. Red. Roman Czaja. T. 5: Małopolska. Red. Zdzisław Noga. Z. 1: Kraków. Red. Zdzisław Noga. Kraków: Towarzystwo Miłośników Historii i Zabytków Krakowa: Wydawnictwo Antykwa, 2007.

Bartel Wojciech M.: Ustrój i prawo Wolnego Miasta Krakowa (1815-1846). Biblioteka Krakowska nr 116. Kraków: Wydawnictwo Literackie, 1976.

Bieniarzówna Janina, Małecki Jan M.: Dzieje Krakowa. T. 3: Kraków w latach 1796-1918. Kraków: Wydawnictwo Literackie, 1979.

Dobrowolska Danuta, Keckowa Antonina: Solnictwo. W: Zarys dziejów górnictwa na ziemiach polskich, t. 2. Red. Jan Pazdur. Katowice: Wydawnictwo Górniczo-Hutnicze, 1961.

Dziwik Kazimierz: Katalog dokumentów Muzeum Żup Krakowskich z lat 1492-1777. Wieliczka: Muzeum Żup Wielickich, 1979.

Dziwik Kazimierz: Katalog rękopisów Muzeum Żup Krakowskich z lat 1518-1971. Wieliczka: Muzeum Żup Wielickich, 1988.

Dziwik Kazimierz: Saliny Krakowskie w latach 1772-1918. W: Dzieje Żup Krakowskich, Wieliczka: Muzeum Żup Wielickich, 1988.

Ihnatowicz Ireneusz: Vademecum do badań nad historiq XIX i XX wieku, t. 1. Warszawa: Państwowe Wydawnictwo Naukowe, 1967.

Keckowa Antonina: Solnictwo. W: Zarys dziejów górnictwa na ziemiach polskich, t. 1. Red. Jan Pazdur. Katowice: Wydawnictwo Górniczo-Hutnicze, 1960.

Kopff Wiktor: Wspomnienia z ostatnich lat Rzeczypospolitej Krakowskiej. Biblioteka Krakowska nr 31. Kraków: Towarzystwo Miłośników Historii i Zabytków Krakowa, 1906.

Kopff Wiktor: Zdanie sprawy o stanie i położeniu Kraju WMK i Jego Okregu w Zgromadzeniu Reprezentantów w 1844 r. przez Senatora do tegoż Zgromadzenia delegowanego. Dodatek do Dziennika Praw Wolnego Miasta Krakowa z 1844 r. Kraków: Drukarnia S. Gieszkowskiego, 1844. 
Kosim Jan: Losy pewnej fortuny: z dziejów burżuazji warszawskiej w latach 1807-1830. Wrocław: Zakład Narodowy im. Ossolińskich, 1972.

Kowalczyk Rafał: Polityka gospodarcza i finansowa Księstwa Warszawskiego w latach 1807-1812. Łódź: Wydawnictwo Uniwersytetu Łódzkiego, 2010.

Kowalczyk Rafał: „Polityka solna” w Księstwie Warszawskim w latach 1807-1815. „Przegląd Historyczny" 2009, t. 100, z. 4, s. 761-780.

Międzobrodzka Małgorzata: Handel solq w wielkim Krakowie. „Studia i Materiały do Dziejów Żup Solnych w Polsce" 2007, t. 25, s. 11-25.

Międzobrodzka Małgorzata: Kazimierski-Podgórski skład solny (XVI-XIX w.). „Studia i Materiały do Dziejów Żup Solnych w Polsce" 2016, t. 22, s. 9-57.

Międzobrodzka Małgorzata: Zbyt soli galicyjskiej na tereny Rzeczypospolitej po I rozbiorze kraju (do 1792 roku). „Studia i Materiały do Dziejów Żup Solnych w Polsce” 1997, t. 20, s. 77-104.

Rederowa Danuta: Studia nad wewnętrznymi dziejami Krakowa porozbiorowego (17961809). Cz. 1: Zagadnienia urbanistyczne. Wrocław: Zakład Narodowy im. Ossolińskich, Towarzystwo Miłośników Historii i Zabytków Krakowa, 1958.

Rożek Michał: Przewodnik po zabytkach i kulturze Krakowa. Warszawa: Państwowe Wydawnictwo Naukowe, 1993.

Rzepka Leszek: Austriackie akta normatywne 1750-1868 w zasobie Archiwum Muzeum Żup Krakowskich Wieliczka. „Studia i Materiały do Dziejów Żup Solnych w Polsce” 2011, t. 27, s. 317-320.

Rzepka Leszek: Informator o zasobie historycznym Archiwum Muzeum Żup Krakowskich Wieliczka. „Studia i Materiały do Dziejów Żup Solnych w Polsce” 1996, t. 19, s. 239-249.

Rzepka Leszek, Marynowski Marcin: Inwentarz Akt Salinarnych Wieliczki i Bochni z lat 1772-1918. Wieliczka: Muzeum Żup Krakowskich Wieliczka, 2004.

Wachholz Szczęsny: Rzeczpospolita Krakowska (okres od 1815 do 1830 r.). Warszawa: Wydawnictwo Prawnicze, 1957.

Walczy Łukasz: Przemiany organizacyjne oraz kadra urzędnicza w Żupach Krakowskich w poczatkowym okresie administracji austriackiej (1772-1809). „Studia i Materiały do Dziejów Żup Solnych w Polsce” 1996, t. 19, s. 111-156.

Walczy Łukasz: Zarzqdzanie salinami krakowskimi w okresie zaboru austriackiego (17721918). „Studia i Materiały do Dziejów Żup Solnych w Polsce” 2002, t. 22, s. 57-78.

\section{PODSUMOWANIE \\ Monopol solny w Wolnym Mieście Krakowie (1815-1846). Organizacja i zakres kompetencji Straży Solnej Wolnego Miasta Krakowa}

Artykuł dotyczy organizacji i form działalności Straży Solnej w Wolnym Mieście Krakowie na tle zasad wykonywania monopolu solnego przez władze Rzeczypospolitej Krakowskiej w latach 1815-1847. Sól była sprowadzana z żup w Wieliczce. W latach 1816- 
1822 korzystanie z monopolu solnego wydzierżawiano prywatnej Kompanii Handlowej Solnej z Warszawy. Jej wspólnicy, w zamian za uiszczanie opłaty dzierżawnej, otrzymali wyłączne prawo sprowadzania i sprzedaży soli na terytorium Rzeczypospolitej Krakowskiej. Spoczywało na nich również utrzymywanie Straży Solnej, we współpracy ze służbą policyjną Wolnego Miasta Krakowa, zapobiegającej przemytowi soli („defraudacje solne”). W latach 1822-1842 monopol wydzierżawiano rządowi Królestwa Polskiego. Warunki umowy nie uległy większym modyfikacjom. Strażnicy solni podlegali pod względem służbowym - rządowi Królestwa Polskiego, pod względem jurysdykcji - Senatowi Rządzącemu WMK. Nosili oni mundury z emblematami Wolnego Miasta Krakowa. Należy dodać, że zasady wykonywania dzierżawy były związane z warunkami traktatów handlowych między obu krajami (z lat 1823 i 1834). W związku z ich nieprzedłużeniem, od 1 czerwca 1843 r. sprzedaż soli przeszła w bezpośredni zarząd Wolnego Miasta Krakowa, które podpisywało z prywatnymi przedsiębiorcami (,etreprenerami”) umowy o transport soli do miasta. Byli nimi Alfus Majer, Franciszek Ripper oraz Franciszek Dąbrowski. Utworzono również Administrację Solną WMK, którą stanowili: naczelnik (M. Mączeński), pisarz Magazynu Solnego (O. Orłowski), kontroler (A. Oraczewski), stróże magazynowi, dozorca Straży Solnej (W. Wilczyński) oraz kilkunastu strażników. Zakres ich kompetencji określono w instrukcjach z 25, 27 i 31 maja 1843 r. Naczelnik nadzorował podległych urzędników, kontrolował Magazyn Solny, składał sprawozdania Wydziałowi Dochodów Publicznych itp. Urzędnicy Administracji Solnej odpowiadali za zaopatrzenie Magazynu Solnego w sól. Strażnicy mieli zapobiegać próbom nielegalnego jej sprowadzania do WMK, kontrolowali szynkarzy solnych itd.

Administracja Solna funkcjonowała do 1847 r. Została zlikwidowana w związku z wcieleniem Rzeczypospolitej Krakowskiej do cesarstwa austriackiego i wynikającą stąd zmianą właściciela monopolu solnego. Należy dodać, że wpływy do budżetu z monopolu solnego były w całym okresie Wolnego Miasta Krakowa bardzo znaczące (od 120-195 tys. złp rocznie, czyli od 9-18\% całości dochodów państwa). Opracowanie oparto w głównej mierze na bogatych materiałach źródłowych przechowywanych w Archiwum Narodowym w Krakowie.

\section{SUMMARY \\ Salt monopoly in the Free City of Krakow (1815-1846). Organisation and range of competencies of the Salt Guards in the Free City of Krakow}

The article concerns the organisation and activities of the Salt Guards in the Free City of Krakow against a backdrop of the salt monopoly entered into by the authorities of the Republic of Krakow in the years 1815-1847. Salt was transported from the mine in Wieliczka. In the years 1816-1822 a salt monopoly was held by the private Salt Trading Company from Warsaw. Its partners, in exchange for the payment of fees, were awarded exclusive rights to transport and sell salt in the territory of the Republic of Krakow. It was also responsible for maintaining the Salt Guards, in cooperation with the police of the Free City of Krakow, preventing the smuggling of salt ("salt fraud"). In the years 1822-1842 the monopoly 
was granted to the government of the Kingdom of Poland. The contract conditions did not undergo major modification. The Salt Guards were subordinate, in terms of service, to the government of the Kingdom of Poland, and in terms of jurisdiction to the Senate of the Free City of Krakow. They wore uniforms with the emblems of the Free City of Krakow. It should be added that the principles behind the monopoly were connected with the conditions of the trading treaties between both countries (from 1823 and 1834). Due to the fact that they were not extended, from 1 June 1843, the sale of salt moved into the direct jurisdiction of the Free City of Krakow, which signed agreements with private entrepreneurs regarding the transport of salt to the city. They were Alfus Majer, Franciszek Ripper and Franciszek Dąbrowski. The Salt Administration of the Free City of Krakow was also established and consisted of: a head (M. Mączeński), scribe of the Salt Warehouse (O. Orłowski), controller (A. Oraczewski), warehouse guard, Salt Guards supervisor (W. Wilczyński) and over a dozen guards. The range of their duties was defined in instructions from 25, 27 and 31 May 1843. The head supervised the subordinate clerks, controlled the Salt Warehouse, and submitted reports to the Department of Public Income etc. The clerks of the Salt Administration were responsible for supplying the Salt Warehouse with salt. The guards had to prevent illegal attempts to transport salt to the Free City of Krakow and controlled the salt merchants etc.

The Salt Administration functioned until 1847. It was liquidated due to the incorporation of the Republic of Krakow into the Austrian Empire and the resulting change in the owner of the salt monopoly. It should be added that income to the budget from the salt monopoly was quite significant during the whole period of the Free City of Krakow (from 120-195 thousand zloty per annum, in other words, 9-18\% of the country's total income). The work was based to a large extent on rich source materials stored in the National Archives in Krakow.

SŁOWA KLUCZOWE: Wolne Miasto Kraków, Administracja Solna, sól wielicka, monopol solny

KEY WORDS: Free City of Krakow, Salt Administration, salt from Wieliczka, salt monopoly 